\title{
An Empirical Examination of Representational Equity in Consolidated Governments, 1965-2002*
}

\author{
Christopher J. Acuff ${ }^{\dagger}$
}

\begin{abstract}
Research on the impacts of city-county consolidation often focus on issues relating to efficiency, effectiveness, and economic development; yet, relatively few studies have addressed the issue of racial and ethnic minority representation. While existing research is limited, findings indicate that consolidating city and county governments dilutes minority voting strength and has a disparate impact on minority representation. However, it is not clear if this is a nationwide trend, particularly in preclearance states previously covered by the Voting Rights Act. Thus, the question becomes, does consolidation negatively affect minority representation, and to what extent? This study employs a quasi-experimental interrupted time-series analysis in order to ascertain the overall impact of consolidation on the descriptive representation of African Americans since 1965. Results indicate that while representation has increased in recent decades, there are discernible declines in following consolidation, and noticeable representational disparities in counties previously covered by the Voting Rights Act.
\end{abstract}

"Forthcoming, Urban Affairs Review.

${ }^{\dagger}$ Assistant Professor, Department of Political Science \& Public Service, The University of Tennessee at Chattanooga. Christopher-Acuff@utc.edu. 


\section{City-County Consolidation \& Representation}

Local government officials and those with a vested interest in their communities have long promoted the idea of structural reforms and boundary change as a means of addressing challenges faced in metropolitan areas. While somewhat rare compared to local government collaboration or changes brought about by annexation or the formation of special districts (Carr and Feiock 2004), the consolidation of city and county governments, in which a "major municipality and county have structurally merged to form a unified government" has been debated in a number of communities as a purported solution to problems stemming from issues such as fragmentation (Leland and Thurmaier 2010, p. 272). Currently, there are 44 consolidated city-county governments in the United States, ranging from large metropolitan areas to more rural locales. Each local government is unique-with different resources, demographics, and challenges_-but common reasons for consolidation can generally be classified with several overarching goals in mind. Typically, considerations such as efficiency, utilization of economies of scale, more effective service delivery, and economic development are arguments made by proponents of consolidation efforts. While there are certainly theoretical arguments to be made in favor of city-county consolidation efforts, results remain mixed, and many within the academic community remain skeptical as to whether local governments and citizens truly benefit as a result (Leland and Thurmaier 2004; Leland and Thurmaier 2010; Martin and Schiff 2011; Selden and Campbell 2000).

Aside from the debate over the outcomes of city-county consolidation cases, Martin and Schiff (2011) explain that an unintended consequence of consolidation is the impact on ethnic minority representation. Further, Swanson (2000) and Bollens (2003) argue that consolidating city and county governments can have a disparate impact on minorities, and those of lower socioeconomic status. As an important distinction, Welch and Bledsoe (1988) explain the two forms of representation commonly addressed in the literature: descriptive representation and substantive representation. Descriptive representation 
(or sometimes passive representation) refers to the "policymaking positions of individuals whose salient social characteristics reflect those in the constituency as a whole," while substantive (or active) representation "refers to whether the policies of the representative are in the interests of the represented" (Welch and Bledsoe 1988, p. xvii). While both concepts of representation are certainly important, descriptive representation has often been the most widely-used characteristic in analyzing and evaluating minority representation.

Although a number of studies on city-county consolidations cite an adverse effect on minority groups, there is little empirical evidence of this in current literature. As Leland and Thurmaier (2004) explain, the collective literature on consolidation efforts "is a patchwork of theoretical concepts and causal models that lack a careful synthesis to permit scholars and practitioners to draw inferences from what we know about the consolidation efforts to date." (p. 5). Beyond a limited number of case studies, questions remain as to the extent to which minority groups are adversely affected by consolidation and if structural and electoral changes are linked to measurable differences in representation. With that in mind, this study attempts to present more generalizable evidence in addressing the impact consolidation can have on the representation of racial and ethnic minority communities in local governments following the passage of the Voting Rights Act of 1965. As such, the following analysis will explore descriptive representation in city-county governments since 1965, utilizing a quasi-experimental, interrupted time-series design in order to examine the changes in representation over time, as well as both pre-and post-consolidation. In all, the information presented will address the following questions: What impact does citycounty consolidation have on African-American representation? What patterns emerge in consolidated city-county governments over time? What impact has the Voting Rights Act had on the implementation of consolidation plans in areas covered by preclearance provisions? 


\section{Representation \& Reform}

Trounstine (2010) provides a comprehensive review of the literature on representation in metropolitan areas, noting some inconsistencies on the impact that structural reforms have had on minority voters. For instance, it is unclear as to what specific factors lead to the election of minority candidates-be it the number of available resources, voter turnout, or the role that reformed institutions play (Trounstine 2010). As Trounstine and Valdini (2008) explain, many scholars subscribe to the conventional theory that "concentration drives the relationship between district elections and representation of racial and ethnic minorities;" however, according to the authors, a great deal remains untested. This is particularly true in the case of consolidation.

While many studies reference the negative impact—or potential negative impact—that consolidation has had or will have on African-Americans, in particular, a great deal of this is grounded in the "conventional wisdom," which may largely be anecdotal. Much of this rests of the argument that racial and ethnic minorities benefit from enhanced representation in local governments with unreformed structures such as electoral districts and partisan elections (Leland and Johnson 2004). However, the question remains as to whether consolidation is, in itself, a distinct type of reform, with potentially different impacts on representation and various subgroups, or are outcomes similar to the existing theories regarding council and electoral structure? Further, as Leland and Johnson (2004) point out, many questions about how best to achieve "fair" representation, and "whether or not increased minority representation on governing bodies will result in public policies more favorable to the minority community" still need further development (p. 31).

Few scholars would argue with the fact that many of the reforms promoted during the late Nineteenth and early Twentieth Centuries had a disparate impact on minority groups. For instance, Davidson and Korbel (1981) note the prevalence of at-large elections in the South, which were often used to dilute minority voting strength. One of the major obstacles in cases of vote dilution, however, is proving intent. As Welch and Bledsoe (1988) 
explain, public officials actively pursuing a strategy of vote dilution do not explicitly sate their intentions or lave behind evidence as such. Because of this, the burden of proof shifted for plaintiffs challenging vote dilution under Section 2 of the Voting Rights Act following the Supreme Court's decision in City of Mobile v. Bolden (1980). Prior to the ruling, plaintiffs had to demonstrate an "intent to discriminate for at-large electoral systems to be invalidated;" however, subsequent to this, "plaintiffs would need only show that an electoral system had the effect or result of diluting minority group influence to prevail" (Bullock 1995, p. 142). Yet, while earlier reforms had the effect—if not the intent-of vote dilution, many previously reformed structures, such as at-large districts, have either been abandoned or modified to include a mixed structure of district and and-large seats (Welch 1990). The question remains, however, as to what extent the intent (Marando 1979), or the unintended consequence (Martin and Schiff 2011) of consolidation continues to have an impact on communities of color more than five decades after the passage of the Voting Rights Act.

From a general perspective, arguments for and against consolidation rest on the tradeoffs and fundamental differences between more centralized and more fragmented government. Historically, government reformers viewed structural reforms such as consolidation as a means of achieving better outcomes relating to efficiency, effectiveness, or economies of scale, while scholars of the public choice tradition argued that competition-inherent in fragmentation-would lead to these same goals (e.g. Ostrom 1972). With regard to metropolitan governance, Banfield (1957) noted that " $[\mathrm{t}]$ he problem is not...merely one of creating organization for effective planning and administration. It is also-and perhaps primarily-one of creating, or of maintaining, organization for the effective management of conflict, especially of conflict arising from the growing cleavages of race and class" (p. 90). Further, Altshuler et al. (1999) argue that "there may be a trade-off between the values associated with equity (in particular, the reduction of unequal opportunity) and values that have undergirded the traditional American system of local government, such 
as efficiency, choice, and local autonomy" (p. 105).

It seems evident that political and social attitudes are likely to have an effect on electoral outcomes, and that reduced racial divides, coupled with White voters who are more willing to ignore race and vote for minority candidates "would mean that minority success is no longer dependent on minority turnout" (Hajnal 2010, p. 93). Despite a general increase in descriptive representation across the country in recent decades, racial and ethnic minorities are drastically under-represented on many local government councils and commissions. Compounding this problem, consolidated city-county governments often carry a stigma that the act of consolidation drastically dilutes minority voting strengthparticularly among African-Americans.

As Marando (1979) observed, "the race issue-specifically dilution of Black voting power-has been considered by many observers to be a hidden objective" of consolidation (p. 414). In a more recent example, Savitch and Vogel (2004) note that LouisvilleJefferson County saw African-American representation on the council fall from 33\% to $23 \%$, despite reformers' advocacy for the merger as a way to enhance minority representation (Savitch and Vogel 2004a). To this end, Clarke (2006) argues that "the elimination of the city government undermines minority voting strength and results in dilution where the region's racial minorities are concentrated in the city," and that because of this, "jurisdictions are required [under the Voting Rights Act] to create rules that ensure a commensurate level of power and voting strength post-consolidation" (pp. 646-647). Clarke goes on to explain that "studies have long identified and recognized that consolidation and government reorganization are tools that can be manipulated and used to dilute African-American voting strength" (Clarke 2006, p. 662).

While Davidson and Korbel (1981) have also found evidence of vote dilution, they note that in many cases where cities and counties have smaller minority populations, it would be difficult for a minority candidate to win, regardless of whether or not elections are wards or at-large districts. Additionally, it is important to point out that different 
minority groups benefit from different electoral arrangements. As Lien et al. (2009) point out, while African-Americans certainly benefit from majority-minority districts, "compared to Blacks, Latinos need a much higher concentration of their own ethnic population in the county to elect Latinos into local offices" (p. 492).

However, as Pitkin (1967) argues, "even the best of representative institutions cannot be expected to produce representation magically, mechanically, without or even in spite of beliefs, attitudes, and intentions of the people operating the system;" rather, the concept of representation is simply a "continuing tension between ideal and achievement" (pp. 239-240). As Pitkin (1967) explains, the concept of descriptive representation entails an accurate reflection of the electorate and that that substantive representation "means acting in the interest of the represented, in a manner responsive to them" (p. 209). Beyond conceptual definitions, philosophers and scholars differ as to how elected officials represent their constituents—be it their interests, their characteristics, their actions, their backgrounds, or their beliefs. Further, Pitkin (1967) also explains that "[n]o institutional system can guarantee the essence, the substance of representation;" and warns that we should not be too optimistic "about the capacity of institutions to produce the desired conduct" (p. 239). Thus, it is important to remember that both concepts or forms of representation are inherently important, descriptive representation has often been the most widely-used characteristic in analyzing and evaluating minority representation based on the assumption that elected officials representative of the constituents they serve will lead to responsive policymaking and, arguably, more equitable outcomes. As such, this study will focus specifically on descriptive representation of African-Americans in consolidated governments, the makeup of legislative bodies are not deterministic; rather, they are simply indicative of the impact structural changes can have in many locales, particularly those in the South. 


\section{Consolidation in the South}

As Rusk (2003) notes, many of the consolidated governments in the United States exist in the South. Both Rusk (2003) and Leland and Thurmaier (2010) explain that state and local laws governing the process by which consolidations may take place are more favorable in this particular part of the country. Further, Leland and Thurmaier (2010) offer "diffusion of innovation" as a potential explanation, in that local government officials in the region—or even the same state-look to similar, nearby cases and adopt structural changes that are viewed as successful. Additionally, Lyons (1977) offers similar insight as to the southern phenomenon, explaining that the southern states tend to have only two types of general-purpose governments-counties and municipalities-as opposed to northeastern states which often have, for instance, townships.

Leland and Thurmaier (2004) also note the prevalence of this occurrence, noting that with few exceptions, the overwhelming majority of consolidations taking place in recent decades have occurred in the South, with a strong prevalence in the State of Georgia. Interestingly, of all the cases of consolidation from the 1980s to the present, 13 of 17 have occurred in the South, with seven of the 13 located in the State of Georgia alone. What accounts for this prevalence? While this question has largely gone unexplored, Fleischmann (2000) has offered some preliminary explanations to this question. Fleischmann (2000) attributes the frequency of consolidation in Georgia, in part, to the number of counties in the state (159 total, second only to Texas), and a desire of both state and local officials to "redress what many perceive as both too many governments and too little local coordination among them" (p. 215).

However, other factors unique to the South, and Georgia, in particular, are related to coverage under the Voting Rights Act and the sizable African American populations in many parts of the region. Following the passage of the Voting Rights Act of 1965, and subsequent reauthorizations, Georgia was included as one of the nine states covered as a whole which had to submit electoral changes to the Department of Justice for preclear- 
ance review. Marando (1979) argues that as African-Americans "approached political control of the central cities of the South, consolidation has been proposed to enlarge the geographic area of the central city to encompass 'whiter' suburban rings" with the intent of diluting the African-American vote (p. 414). Further, Feiock, Carr, and Johnson (2006) note that in earlier consolidation cases, occurring through the 1960s, race largely shaped the campaigns by exploiting both racial tensions and latent attitudes within the community. Similar to Marando (1979), Feiock, Carr, and Johnson (2006) argue that successful consolidation efforts during this period were bolstered by proponents "suggesting that consolidation would be an effective mechanism to stunt growing African-American political power or to prevent African-Americans from ever gaining significant power" (p. 277). Together, these elements related to race and dilution, coupled with the fact that consolidation is primarily a southern phenomenon, raise important questions as to the implications for measuring representation in this region assessing the impact of the Voting Rights Act's preclearance provisions have had in many southern states.

\section{Racial and Ethnic Representation in Local Government}

For decades, scholars have examined the impact of electoral structures and voting policies on racial and ethnic minorities. While many studies tend to focus on congressional districts and redistricting, a great deal of literature has examined the nature of local government structures and the impacts of electoral arrangements dating back to Jim Crow and the Progressive Era. Despite a general increase since the Civil Rights Era in African-Americans' descriptive representation at all levels of government (Bositis 2002; United States Census Bureau 2010), minorities are drastically under-represented on many local government councils and commissions, and consolidated city-county governments carry a stigma that the act of consolidation drastically dilutes minority voting strength. Martin and Schiff (2011) note that despite much of the debate surrounding city-county consolidation focus- 
ing on outcomes related to efficiency, effectiveness, or accountability, an unintended consequence of consolidation is the impact on ethnic minority representation. For instance, Swanson (2000), building on previous work from Seamon and Feiock (1995), notes that voter turnout in the 19 years after consolidation in Jacksonville-Duval County, Florida had dropped by $18 \%$-more than any other urban area in Florida.

At-large elections, promoted heavily during the Progressive Era, were supported by reformers as a means of creating local government structures where elected officials, and, by extension, their policies, would be focused more on the municipality as a whole, rather than specific districts and various segments of the community. It was thought that by reducing the competition that often occurs when allocating resources and making political decisions that may benefit one particular group or neighborhood, greater cooperation and improved governance would result. Thus, by policymakers taking a more holistic perspective rather than focusing on specific segments of the population, or only considering more short-term political interests, more equitable outcomes would be achieved (Leland and Johnson 2004). The problems that result, however, in taking an at-large perspective to governance is that certain subgroups within a municipality are excluded, and often not considered when crafting policies, allocating resources, or representing particular interests when those groups constitute a minority of the population. As such, many scholars point to at-large elections as the most frequent institutional barrier that minority groups have to overcome.

Hajnal (2010) also cites small council size, nonpartisan elections, off-cycle elections, and council-manager form of government as other institutional barriers that make it difficult for minorities to attain office. In many consolidated governments, reducing council size, changing to or maintaining a system of nonpartisan elections, and scheduling off-cycle elections-and even the consolidation referenda themselves-often occur in these locales. Complicating matters, as Welch and Bledsoe (1988) point out, is the fact that despite at-large systems having been used to discriminate against minority voters-particularly 
African-Americans-proving that fact has been rather difficult when it comes to the courts. In short, "public officials rarely, if ever, leave behind a well-documented record of their illicit motives" (Welch and Bledsoe 1988, p. 13). In all, these factors make it clear that structural changes have negatively impacted racial and ethnic representation in local governments, particularly in consolidated governments, which often possess several of the characteristics described above; however, establishing clear connections between either the intent or the impact of these structural changes has been difficult to demonstrate from a comprehensive perspective.

\section{Measuring the Disparate Impact of Consolidation}

In order to test whether consolidation has a disparate impact on racial and ethnic minority representation, this paper explores how consolidation has impacted the election of AfricanAmericans following the passage of the Voting Rights Act of 1965. For this analysis, each consolidated legislative body was used as the focus in this study in order to test representational equity both cross-sectionally, following consolidation, as well as temporally, in order to observe changes in minority representation over time. Similar to previous comparative case studies on consolidation, demographic and economic variables were used to match cases based on the year of consolidation, as the key to this type of research design in "comparing the cases with respect to the point of departure as a consolidated government structure" (Leland and Thurmaier 2010, p. 16). When analyzing many aspects of consolidation, Leland and Thurmaier (2010) note that the most important demographic variable is population size, as well as other factors, including median age, education, and income. Further, it is also important to select cases from the same state, which allows for the control of "fiscal, legal (constitutional and statutory), and political constraints and influences on cities, counties, and consolidated governments" (p. 18).

Further, Dluhy (2010) also explains that it is important to match consolidated cases 
with other governments based on socioeconomic factors, and also account for forms of government and electoral structures. In the instance of a selected case also being an existing consolidated government, the second most-similar case was selected (Swartz 2010). Further, Swartz (2010) echoes King, Keohane, and Verba (1994), as well as Yin (2003) in emphasizing both the importance and the benefits of drawing on multiple sources and methods of data collection and notes that multiple sources allow for triangulation, which addresses the issue construct validity by providing "multiple measures of the same phenomenon" (Yin 2003, p. 99). For these reasons, testing representational equity both before and after (similar to Davidson and Grofman 1994), as well as over time, are appropriate in order to establish better estimates of any potential effect structural changes resulting from consolidation have on minority representation.

While a random sample is typically the preferred method in purely quantitative research with large- $N$ analyses so as to avoid selection bias, the most appropriate selection method for a great deal of small- $N$ studies is to select cases nonrandomly (King, Keohane, and Verba 1994; Brady and Collier 2010). King, Keohane, and Verba (1994) warn against selecting cases based on the dependent variable, as well as avoiding cases that that have little to no variation in the independent variables; however, limitations stemming from small- $N$ analyses and problems with selection biases can be mitigated by paying careful attention to internal validity and thoughtful case selection (Leland and Thurmaier 2010). George and Bennett (2005) note that "The best known method is the method of 'controlled comparison'-i.e., the comparison of 'most similar' cases which, ideally, are cases that are comparable in all respects except for the independent variable, whose variance may account for the cases having different outcomes on the dependent variable" (p. 80). In order to accomplish this, a "controlled comparison can be achieved by dividing a single longitudinal case into two-the 'before' case and an 'after' case that follows a discontinuous change in an important variable" (George and Bennett 2005, p. 80).

Consolidation cases post-1965 were used in order to include those cases which oc- 
curred after the passage of the Voting Rights Act (VRA), assuming that structural barriers to the ballot box will have been minimized or removed. Data from the pre-and postconsolidation periods were collected in order to effectively evaluate the level of representation (similar to Leland and Thurmaier 2010), in addition to longitudinal data for the entire time-series. Unfortunately, comprehensive data on African-American elected officials (discussed below) in local governments are only available through 2002, which limits the analysis to 19 cases $^{1}$ that consolidated between the years 1965 and 2002. In cases where the best-matched county was another consolidated government in that state, the next-best comparison case was chosen using the variables of interest. Additionally, as research has shown that district (ward) or "mixed" systems (in which a government has representatives elected from both districts and at-large) tend to be favorable in achieving more equitable descriptive representation for racial and ethnic minorities (e.g. Welch 1990; Hajnal and Trounstine 2005; Trounstine and Valdini 2008), to the extent possible, an appropriate match was found for each consolidated government's electoral structure. ${ }^{2}$ Finally, for the purposes of comparison, the city and county legislative bodies for both the pre-consolidation cases as well as the non-consolidated control cases were combined in order to achieve a comparable ratio and basis for comparison both before and after consolidation (similar to Swartz 2010). In order to examine the impact of consolidation on representational equity, the basic hypotheses to be tested as as follows:

Hypothesis 1 Representational equity will decrease in consolidated city-county governments in the years following consolidation.

Hypothesis 2 Representational equity will increase year-to-year, following the passage of the Voting Rights Act of 1965.

Hypothesis 3 Representational equity will decrease following consolidation in states not considered "preclearance" states under the Voting Rights Act. 


\section{Data \& Methods}

To determine the changes in representational equity before and after consolidation, an interrupted time-series design is used, incorporating a non-equivalent control group in order to compare changes over time in similar cases (Cook and Campbell 1979; Leland and Thurmaier 2010). The intervention, or treatment variable, in these cases, is consolidation of the city and county governments $\left(C^{3}\right)$. Adapted from Leland and Thurmaier (2010), the basic model takes on the following form, with $O_{t}$ representing an observation year from 1965-2002:

\begin{tabular}{llllll} 
Experimental Group (consolidated): & $O_{1}$ & $\ldots$ & $\mathrm{C}^{3}$ & $\ldots$ & $O_{n}$ \\
\hline Control Group (unconsolidated): & $O_{1}$ & $\ldots$ & & $\ldots$ & $O_{n}$
\end{tabular}

The data used were collected from existing sources, including Davidson and Grofman (1994), the Joint Center for Political and Economic Studies' National Roster of Black Elected Officials (1970-2002), the United States Commission on Civil Rights (1968), and the Southern Regional Council (1984) in order to build a comprehensive dataset that effectively captures the makeup of the legislative bodies in question. These rosters will be used to calculate the equity ratio, which will be used as the dependent variable, following a similar method employed by Polinard et al. (1994). Polinard et al. (1994) calculate a ratio of representational equity by "dividing the percentage of Mexican Americans on the council by the percentage of Mexican Americans in the community" where an "equity ratio of 1.00 would result if a city with a Mexican American population percentage of 33 percent had a city council whose composition were one-third Mexican American" (p. 119). Thus, the dependent variable used in this analysis is the ratio of the percentage of Black elected officials on the governing bodies to the percentage of the Black population in each county. First developed by Karnig (1976), a similar measure has been used previously by a numbr of schoalrs when examining electoral structures (e.g. Robinson and Dye 1978; Karnig 1979; Heilig and Mundt 1983). As Karnig (1976) explains, a "ratio exceeding 1.00 
designates overrepresentation...while a ratio below 1.00 indicates underrepresentation" (p. 225). While some government bodies may be more equitable than others, it would be surprising to find an equity ratio that exemplified a "perfect parity" between the council and the community.

It should be noted that while there is some criticism of this measure (e.g. MacManus 1978; Taebel 1978; Karnig and Welch 1982) stemming from the fact that many cities and counties have historically not elected any African-Americans, which would result in a number of equity scores equaling zero, this truncation is less evident over such an extended time period. Further, as Karnig and Welch (1982) note, the measures used by MacManus (1978) and Taebel (1978) have their own limitations, and not only present a challenge by being bound at the lower and upper limits (as a measure would be constrained to a range of $\pm 100 \%$ ), but also that a small minority population would result in a slightly negative score, despite having no representation on the legislative body. Here, it should be noted that several of the consolidated and control counties did not elect a single AfricanAmerican during the time period from 1965-2002. ${ }^{3}$

Based on previous studies (e.g. Welch and Bledsoe 1988; Davidson and Grofman 1994; Leland and Thurmaier 2004; Leland and Thurmaier 2010; Hajnal and Trounstine 2005; Hajnal 2010) which demonstrate the importance of various structural, demographic, and socioeconomic factors with regard to local governments and descriptive representation, control cases will be matched based on the following attributes: total population; racial composition; median household income; educational attainment; presidential vote share; form of government; and council structure. ${ }^{4}$ Population and household income are actual values for each county-year, while race, education, and presidential vote share are based on percentages for that year. Race is calculated as the percentage of African-Americans in each county; education represents the percentage of residents holding a Bachelor's degree or higher; presidential vote is calculated as the Republican vote share in the previous presidential election; form of government will be classified based on the executive and 
legislative arrangements for that locale (e.g., mayor-council, council-manager, etc.); and council structure will be classified based on whether officials are elected by district, atlarge, or a combination of the two (similar to Davidson \& Grofman, 1994). Data for case selections was collected from the U.S. Census Bureau's decennial census and Current Population Surveys, as well as from the IPUMS National Historical Geographic Information System database (Manson et al. 2018), with missing values linearly interpolated. ${ }^{5}$ Additionally, it should be noted that the National Roster of Black Elected Officials was not published three years during this time period (1983, 1992, and 1994); thus, values for these three years were also interpolated. Cases were selected based on the actual year that consolidation took effect in order for that year to serve as the year of intervention. This yielded the cases listed in Table 1, which are most similar to each consolidated city-county government (shown in bold) in the year of consolidation.

\section{[TABLE 1 ABOUT HERE]}

In order to determine the impact of consolidation over time, a quasi-experimental interrupted time-series (ITS) design was used in order to explore representational equity over time, as well as both pre-and post-consolidation. ITS designs are prevalent in the literature on boundary and other structural and systemic changes to local and state governments (e.g. Meier 1980; Morgan and Pelissero 1980; Lewis-Beck 1986; Feiock and Carr 1997; Carr and Feiock 1999; King 2002; Benton 2003a; Benton 2003b; Carr, Bae, and Lu 2006; Taylor, Faulk, and Schaal 2017). A basic ITS design is appropriate in instances of significant political or policy shifts, where "the investigator is interested in the effect of a relatively discrete event on a phenomenon observed over time" (Lewis-Beck 1986, p. 210). Beyond the research design itself, several different modeling approaches emerge when examining the differences of a discrete policy intervention over time. Whereas several studies (e.g. Feiock and Carr 1997; Carr and Feiock 1999; Carr, Bae, and Lu 2006) have examined trends in economic development employing Auto-Regressive Integrated Moving Averages (i.e. ARIMA models), others have maintained that linear time-series models are also well 
suited for analyzing interventions related to government and policy (e.g. Meier 1980; Morgan and Pelissero 1980; Morgan and Kickham 1999; King 2002; Benton 2003a; Benton 2003b; Taylor, Faulk, and Schaal 2017). While the goal of this analysis is to decipher the average effects of various interventions, time periods, and sociopolitical phenomena on representational equity, individual-level county models-including further discussion of ARIMA and linear results-are included in the appendices. In all, both linear and ARIMA models perform reasonably well in demonstrating the underlying trends for individual counties. However, linear models were chosen for this analysis in order to incorporate additional factors that help explain differences in representational equity beyond a basic time trend and intervention.

As such, the goal of this study is to develop more a more generalizable assessment of the impact consolidation has on representational equity. Here, we would expect a change in representational equity to be immediate, in addition to lasting effects over time. Thus, an autoregressive term, while appropriate for more gradual changes stemming from a structural change such as consolidation on the financial condition of the city, or the business and employment patterns of the area area are warranted, such an approach may underestimate the immediate impact of the intervention (here, consolidation) in these cases. Thus, drawing from these analyses that employ a basic linear model, (e.g. Meier 1980; Morgan and Pelissero 1980; Lewis-Beck 1986; King 2002; Benton 2003a; Benton 2003b; Taylor, Faulk, and Schaal 2017) the following model is used to assess the impact of consolidation on the representational equity of African-Americans in local government:

$$
Y_{i t}=\beta_{0}+\beta_{1} T_{1 t}+\beta_{2} X_{t}+\beta_{3}\left(T_{1 t} \times X_{t}\right)+\beta_{4} X_{2}+\beta_{5}\left(X_{2} \times X_{3}\right)+\epsilon_{t}
$$

Where $Y_{i t}$ represents the representational equity for each government in each year; $T_{1 t}$ (Time) represents the linear trend for each year, beginning in 1965; $X_{t}$ (Post-Consolidation) is a dummy variable, indicating consolidation $(1=$ consolidation in that year and thereafter; $0=$ no consolidation); $T_{1 t} \times X_{t}$ is the interaction of Time and Consolidation; $X_{2}$ 
(VRA Preclearance) represents a dummy variable for governments in states or counties covered under the preclearance formula and provisions in Sections 4(b) and 5 of the Voting Rights Act ( $X_{2}=1$ for coverage; 0 for non-coverage); $X_{3}$ represents a dummy variable for consolidated cases ( $X_{3}=1$ for consolidated; 0 for non-consolidated cases), including the interaction term with $X_{2}(V R A \times$ Consolidated Government $)$; and $\epsilon_{t}$ is the error term. The intervention-consolidation, in this case-is the year a city-county government consolidated, not the year in which consolidation was approved by referendum or state legislature.

\section{Results}

Results from the time-series for the years 1965-2002 are presented in Table 2, including panel-corrected standard errors, and includes the year-to-year temporal factor (Time), in addition to the post-consolidation indicator (Post-Consolidation) and the interaction between the two (Time $\times$ Post-Consolidation). Additionally, Models 1-3 include an indicator for counties under the Voting Rights Act's preclearance provisions (VRA Preclearance), as well as the interaction between VRA preclearance status and the post-consolidation period (VRA $\times$ Consolidated Government), assuming a "treatment" stemming from approval from the United States Department of Justice, tasked with reviewing consolidation charters and analyzing the potential impact on racial and ethnic minority communities. These results are also presented graphically, in Figure 1, as a forest plot in order to compare the coefficients in each of the three models.

\section{[TABLE 2 \& Figure 1 ABOUT HERE]}

In addition to the basic model presented in Model 1, reggressors representing demographic, socioeconomic, and political factors were used to assess the factors that correlate with representational equity in these 19 cases are included in Model 2 (similar to Welch 
and Bledsoe 1988; Hajnal and Trounstine 2005; Trounstine and Valdini 2008) as a robustness check, as a simple pre-and post-intervention analysis may not present the entire picture related to the factors that significantly impact representational equity at the countylevel. Further, as an additional control examining the time period in which consolidation took place, a dummy variable for each decade is introduced in Model 3 (similar to Veiga, Veiga, and Morozumi 2017). Taken together, Models $2 \& 3$ show several significant and illuminating results when examining the potential factors that contribute to higher or lower levels of representational equity in consolidated governments compared to their matched counterparts.

\section{The Impact of Consolidation on Representational Equity Over Time}

Overall, the "conventional wisdom" relating to consolidation-that the merger of city and county governments will decrease descriptive representation-appears to hold true in Models $2 \& 3$ when taken together with the additional control variables discussed above. The Post-Consolidation time period, alone, and its interaction with the year-toyear change over time (Time $\times$ Post-Consolidation) paint a slightly complex picture related to representational equity following consolidation. The binary variable representing the years following consolidation does not indicate that there is a significant change in the post-consolidation period; however, the interaction with Time does show a statistically significant decrease between $1.7 \%$ and $1.9 \%$ in Models $2 \& 3$, respectively. To better illustrate this, Figure 2 shows the marginal year-to-year change in the post-consolidation period. Taken together, these results show support for Hypothesis 1, in that the impact of consolidation does have a negative impact on representational equity when controlling for other factors. However, this effect may diminish in the long-run, and is not significantly different when comparing the entire pre-and post-consolidation periods, rather than the immediate, incremental change.

[FIGURE 2 ABOUT HERE] 
Additionally, when examining the temporal trends in representational equity, the time trend shown in Model 1 (Table 2) and Figure 3a are consistent with Hypothesis 2, with a year-to-year increase of approximately 2.2\%. However, as shown in Models $2 \& 3$, Time is not a significant predictor of a year-to-year change in representational equity when incorporating additional controls in this analysis. As an additional measure of time, dummy variables representing the decades following the implementation of the voting Rights Act were used as further controls on the time periods in which these governments consolidated. As shown in Model 3, compared to the 1960s, governments which consolidated in the 1970s (25.5\%) and 1980s (38.9\%) show significantly higher levels of representational equity compared to the first cases following passage of the VRA. More recent cases in the 1990s (16.7\%) and 2000s (15.6\%) also show significantly higher levels of representational equity (16.7\% and $15.6 \%$, respectively); though, not to the extent of those which occurred in the preceding decades. This leaves room for further exploration as the the impact of demographic, political, or institutional changes, in addition to potential factors related to the VRA's implementation and other alternate explanations affecting these city and county governments that consolidated during these decades.

\section{[FIGURE 3 ABOUT HERE]}

Finally, it should be noted that both Models 2 \& 3 show significantly higher $\mathrm{R}^{2}$ values compared to Model 1, indicating that these additional factors explain much more of the variation in representational equity compared to the baseline model. These additional factors include county-level variables which all appear to positively and significantly impact representational equity in our governments of interest. Larger (log) populations, higher percentages of African-American populations, higher median household incomes, increased percentages of adults 25 or older with a Bachelor's degree, and, somewhat surprisingly, higher Republican vote shares all positively and significantly correlate with higher levels of representational equity on average. It may not be surprising that larger metropolitan areas or locales with higher percentages of African-Americans would elect 
members that more closely reflect the population at higher rates, nor might higher socioeconomic status in the electorate as demonstrated by higher median incomes or the prevalence of more adults with Bachelor's degrees. However, as more African-Americans, and, increasingly, more urban and suburban regions have tended to increasingly support Democratic presidential candidates in recent decades, an increase in Republican presidential vote shares may warrant further analysis when untangling the complexities of politics and its relationship to representational equity in these governments.

\section{Consolidation and Representation in Preclearance States}

Findings presented in Table 2 present mixed results considering the potential impact the Voting Rights Act had on the resulting representational equity in these local governments. Model 1 shows no significant impact of VRA preclearance provisions on representational equity in counties under the Department of Justice's purview. However, we do see a significantly higher level of representational equity in consolidated governments under the VRA's purview, at approximately $26.2 \%$ higher than these counties' non-consolidated counterparts. When controlling for other factors in Models $2 \& 3$, counties with preclearance provisions do demonstrate significantly lower levels of representational equity compared

to those not covered by the VRA. Additionally, Figure 4 shows both the predicted equity ratios for both the VRA Preclearance and VRA $\times$ Consolidated Government coefficients from Model 3 (including 95\% confidence intervals) highlighting the differences for both the VRA preclearance and non-preclearance cases, as well as those subject to VRA provisions which underwent a review by the Department of Justice.

\section{[FIGURE 4 ABOUT HERE]}

While results from Models $2 \& 3$ indicate that representational equity is approximately $45 \%$ lower in preclearance counties compared to those not not subject to the Department of Justice's purview, the interaction term between VRA preclearance and consolidation 
$(V R A \times$ Consolidated Government $)$ show that oversight on the part of the DOJ did, at least in these counties, have a positive effect on representational equity following the merger of city and county governments. It is important to note that the VRA Preclearance coefficient includes all cases subject to VRA preclearance provisions, not just those that consolidated or otherwise would have had to submit electoral changes subject to Department of Justice review. Yet, results from Model 3 show that, on average, post-consolidation counties have an equity ratio approximately $10 \%$ higher than those outside of the scope of VRA provisions which have not consolidated.

On the surface, these results demonstrate that preclearance review of city-county consolidation plans were effective in not only preventing a reduction in African-American representation following a merger, but that descriptive representation actually increased in these cases. Here, it is assumed that counties covered under the VRA which have not consolidated or undergone any significant electoral change have likely not been subject to a comprehensive review by the Department of Justice when it comes to the electoral system in place at the time. As such, the consolidated cases subject to preclearance review offer a promising perspective on the potential impact that comes from oversight of these changes in ensuring that institutional and electoral changes do not have a negative impact on African-American representation; or, at least mitigating those impacts to the extent possible prior to the enactment of a newly-formed government's charter. Thus, we should expect-and hope-that counties which submitted plans for consolidation and underwent review by the Department of Justice would result in some increase in representation following consolation, and these results help substantiate that conclusion, as well as Hypothesis 3. 


\section{Discussion}

\section{Summary and Contributions}

The goal of this study is to further our understanding of a fundamental impact related to city county consolidation that has been somewhat neglected in the literature from a quantitative perspective in order to ascertain more generalizable trends. Although representational equity has generally increased at all levels of government since the passage of the Voting Rights Act of 1965 (Bositis 2002; United States Census Bureau 2010), a number of cities and counties are still well below parity, with many having no African-American officials at all despite relatively sizable ethnic and racial minority populations (Joint Center for Political and Economic Studies 1970-2002). As noted earlier, the "conventional wisdom" regarding city-county consolidation and the impact of racial and ethnic representation seemingly holds true, and all three hypotheses are generally supported; although, with some mixed evidence. Although some of the findings presented may not be a surprise to those familiar with the consolidation literature, this study presents the first attempt to analyze the impact of every consolidation over a nearly 40-year period, and highlight generalizable phenomena affecting representational equity among this subset of unique local governments.

These findings demonstrate that, on average, the consolidation of city and county governments does lead to a significant year-to-year decrease in African-American representation. Additionally, results show that the time period in which governments consolidate can help us better understand the historical and contextual factors that explain AfricanAmerican representation in these governments. Further, counties under the Voting Rights Act's preclearance provisions show higher levels of representational equity, especially compared to non-consolidated governments. And, finally, these analyses indicate that larger populations, larger African-American populations, higher socioeconomic status (as measured by educational attainment and median household incomes), and larger Republican 
vote shares tend to lead to higher levels of representational equity for African-Americans in these local governments. All in all, this study bolsters our understanding of consolidated city-county governments by presenting more generalizable evidence of the impact consolidation can have on minority representation, how descriptive representation has changed over time, and the impact the Voting Rights Act had in communities under preclearance provisions from 1965-2002.

\section{Limitations and Future Research}

While the 19 cases in this analysis include less than half of the 44 consolidated governments in the United States, they represent a diverse cross-section of cases when considering demographic, geographic, historical, and political factors that potentially shape the local government landscape in these city-county governments. However, several considerations must be taken into account when examining results presented in this study. First, it should be noted that while the governments chosen for this study were specifically selected based on the criteria that they consolidated after passage of the Voting Rights Act in order to control for historical and institutional impediments that have depressed African-American representation in the United States, this ignores a number of more recent cases and larger metropolitan cities, considered consolidated governments, which consolidated nearly a century or more prior to the study conducted here. ${ }^{6}$

Additionally, results related to temporal changes in representational equity (Time) and the time period in which consolidation took place (indicated by the decade dummy variables: 1970s-2000s) deserve more nuanced attention. With these findings, the year-toyear temporal change which was statistically significant in Model 1 all but disappeared when controlling for a discrete decade in which a city-county government formed. As a corollary, more in-depth analysis of phenomena that can help explain the significantly higher levels of representational equity in cases that consolidated in the 1970s and 1980s compared to other decades is needed. Additional research focused on demographic changes 
relative to redistricting and other potential institutional changes in these particular local governments and their impacts on racial and ethnic minority representation also deserves further attention. These results may point to factors such as redistricting that fail to keep up with growing African-American populations in these locales or other potential explanations for changes that have gradually eroded representational equity on these councils. Further, these findings raise the question as to whether differences exist with regard to legal or institutional elements influenced by the Department of Justice, court decisions, or other potential circumstances influenced by charter provisions or contextual factors unique to these groups of cases at these particular points in time.

Next, it is important to note that the focus on racial and ethnic minority representation in the consolidation literature often focuses on the relative voting strength of a particular minority community has (or had) in the city compared to the existing or projected levels of representation following a government merger (e.g. Swanson 2000). With the measure employed here, the goal was to hold the "dilution" of the city into the county (relatively) constant by combining the makeup of both legislative bodies pre-consolidation. However, the "dilution" of both descriptive and substantive racial and ethnic minority representation should not be dismissed when it comes to our analyses of structural changes to local governments, districts, or elections. Simply because a particular group's electoral strength remains relatively consistent when measured in the county as a whole does not mean that real concerns should be dismissed when it comes to the potential impacts of institutional and electoral changes. On the contrary, it could be argued that many-or close to allof these cases could result in the relative dilution of minority representation and relative voting power in cases where African-Americans and other non-White groups make up a sizable share of a municipality's population, but less so when encompassing a majority White county as a whole. ${ }^{7}$

Further, Martin and Schiff (2011) identify the need for continued exploration not only related to the impact of consolidation on descriptive representation, but also on substantive 
representation for racial and ethnic minorities and those of lower socioeconomic status. The latter aspect being particularly important for further investigation with the increased focus on economic development in more recent consolidation campaigns, combined with the growing income disparities often seen in metropolitan areas. Measuring the number of elected officials that represent a particular area or constituency is an important first step; however, it is important to know how descriptive representation translates to policy, particularly policies that potentially affect historically marginalized groups.

While the findings presented with regard to decreases in representational equity following consolidation in counties not covered by the VRA are generally what would be expected, more recent data should be collected in order to extend the analysis beyond 2002 and capture more recent cases. As we have seen across the country, representational equity, though still not close to parity in most cases, has generally increased since passage of the Voting Rights Act. Unfortunately, the Joint Center for Political and Economic Studies has not extended the dataset beyond 2002 for local elected officials. Though retroactive collection could be difficult, though, not impossible to collect, it would certainly be beneficial to extend the analysis beyond 2002 in order to capture more recent cases of consolidated city-county governments ${ }^{8}$ and extend the time-series of those which consolidated in the 1990s and early 2000s.

In addition to the impact on African-Americans, one aspect that has essentially gone unexplored is the impact of consolidation on Latino Americans. Based on an examination of data collected by the National Organization of Latino Elected and Appointed Officials, Kansas City-Wyandotte County is the only government consolidated between 1965-2002 that elected one or more Latino officials between 1984 and 2015. With the increase of Latino populations in many metropolitan areas as of late, the chance of electing officials from those traditionally undeserved communities also increases, including those elected to serve consolidated city-county governments. Finally, another aspect of representation that has been completely ignored in the consolidation literature is that of Native American vot- 
ers. Four of the 44 existing consolidated governments are located in Alaska, all of whose boroughs have sizable Native populations, as well as several other boroughs which have held referenda in recent years. Thus, further exploration to determine whether structural changes have the same impact on other groups as that of African-Americans would substantially improve the consolidation literature, specifically, as well as research focusing on local government and urban politics as a whole.

Finally, it should be noted that while this study considers cases that were ultimately successful in terms of consolidation referenda, it does not address factors that contribute to the ultimate success of a consolidation campaign which ultimately shape the consolidated government and its representatives. As shown in Rosenbaum and Kammerer (1974), Leland and Thurmaier (2004), and a number of related articles examining the ultimate success or failure of various consolidation referenda, institutional factors influencing representation play a key role in building winning coalitions in cities where voters are eventually asked to approve of recommended charters. These factors, often developed by charter commissions, shape decisions regarding the size of the legislative body, the timing of elections, the choice whether to have partisan or nonpartisan elections, the redistricting process, and other context-specific factors that can ultimately affect representation in local government. All of these factors heavily influence not only the chances of success or failure with regard to the eventual outcome of a consolidation campaign, but also the eventual structural changes that once implemented, ultimately affect the size, makeup, and powers of a new legislative body.

Thus, in addition to extending the data collection to innclude additional city-county governments, future studies should seek to incorporate these institutional factors that not only contribute to the ultimate success of a consolidation referendum, but also the eventual political landscape that influences who runs for office, which constituents they represent, the timing of elections, and other related factors. As we have seen across the country, challenges of adequate representation play a role in many communities, and many local 
governments—-particularly those with smaller populations—remain vastly understudied in the literature. Continued work on these and related topics will undoubtedly help further our understanding of the impacts structural reforms continue to have in the thousands of local governments across the United States. 


\section{Notes}

${ }^{1}$ Of these 19 matched pairs, it should be noted that data are truncated at years 1965 and 2002. Thus, consolidated governments formed soon after 1965, or approaching 2002, will have fewer data points either pre-or post-consolidation, respectively. Additionally, the merger of the City of Nansemond, Nansemond County, and the independent City of Suffolk are treated as one case, as all three entities merged over the period of $1972-1974$.

${ }^{2}$ Of the 19 consolidated cases, only Haines Borough, Alaska has an at-large electoral system. Two other Alaskan boroughs, Juneau and Sitka, both have a mixed electoral structure; however, the best match based on the aforementioned factors was a borough with an at-large system (with Juneau being the only of these four cases to elect an African-American to its assembly). The remaining 16 matched pairs have either a district or a mixed electoral system.

${ }^{3}$ These include: Deer Lodge, Flathead, Hill, and Silver Bow Counties in Montana; Carson City and Lyon County, Nevada; Moore County, Tennessee; and five boroughs in the State of Alaska, including Haines, Ketchican, Lake \& Peninsula, Nome, and Sitka.

${ }^{4}$ Education and median income data were not available for the Alaska boroughs of Juneau (1970), Sitka (1971), and Anchorage (1975); thus, cases were matched based on population, race, education, and presidential vote. It should also be noted that Alaska reports vote totals by district, rather than by borough. In these cases, the Republican vote shares may include (or exclude) certain areas of each borough matching cases within the state.

${ }^{5}$ Linear interpolation of decennial census data has been widely used for demographic variables and has been shown to produce reliable estimates at the county level (Weden et al. 2015).

${ }^{6}$ These include governments such as New Orleans, Boston, Philadelphia, San Francisco, and New York City, which are often left out of the more modern cases examined when conducting studies focused on consolidated city-county governments.

${ }^{7}$ Of the cases in this study, African-Americans made up a majority of residents in only one city-county government at the time of consolidation: Suffolk County, Virginia. Of the more recent cases of city-county mergers (consolidated after 2002), Macon-Bibb County, Georgia is the only majority African-American locale. However, Georgetown-Quitman County, Georgia (48.5\%) and Preston-Webster County, Georgia (42.2\%) both have sizable African-American populations according to Census Bureau 2019 ACS estimates.

${ }^{8}$ These include five cases in Georgia: Georgetown-Quitman County; Macon-Bibb County; Statenville/Echols County; the Unified Government of Cusseta-Chattahoochee County; and, the Unified Government of Webster County, as well as Unified Greeley County, Kansas and Camden/Camden County, North Carolina. 


\section{Bibliography}

Altshuler, Alan, William Morrill, Harold Wolman, and Faith Mitchell. 1999. Governance and Opportunity in Metropolitan America. Washington, DC: National Academy Press.

Banfield, Edward C. 1957. "The Politics of Metropolitan Area Organization." Midwest Journal of Political Science 1 (1): 77-91.

Benton, J. Edwin. 2003a. "County Government Structure and County Revenue Policy: What's the Connection?" State and Local Government Review 35 (2): 78-89.

_. 2003b. "The Impact of Structural Reform on County Government Service Provision." Social Science Quarterly 84 (4): 858-874.

Bollens, Scott A. 2003. "In Through the Back Door: Social Equity and Regional Governance." Housing Policy Debate 13 (4): 631-657.

Bositis, David A. 2002. Black Elected Officials: A Statistical Summmary, 2000. Washington, DC: Joint Center for Political; Economic Studies.

Brady, Henry E., and David Collier. 2010. Rethinking Social Inquiry: Diverse Tools, Shared Standards. Lanham, MD: Rowman \& Littlefield Publishers.

Bullock, Charles S. 1995. "The Impact of Changing the Racial Composition of Congressional Districts on Legislators' Roll Call Behavior." American Politics Quarterly 23 (2): 141-158.

Carr, Jered B., Sang-Seok Bae, and Wenjue Lu. 2006. "City-County Government and Promises of Economic Development: A Tale of Two Cities." State \& Local Government Review 38 (3): 131-141.

Carr, Jered B., and Richard C. Feiock. 1999. "Metropolitan Government and Economic Development." Urban Affairs Review 34 (3): 476-488.

. 2004. City-County Consolidation and Its Alternatives: Reshaping the Local Government Landscape. Armonk, NY: M.E. Sharpe.

Clarke, Kristen. 2006. "Voting Rights \& City-County Consolidations." Houston Law Review 43 (3): 621-699.

Cook, Thomas D., and Donald Thomas Campbell. 1979. Quasi-Experimentation: Design \& Analysis Issues for Field Settings. Boston, MA: Houghton Mifflin.

Davidson, Chandler, and Bernard Grofman. 1994. Quiet Revolution in the South: The Impact of the Voting Rights Act, 1965-1990. Princeton, NJ: Princeton University Press.

Davidson, Chandler, and George Korbel. 1981. "At-Large Elections and Minority-Group Representation: A Re-Examination of Historical and Contemporary Evidence." The Journal of Politics 43 (4): 982-1005.

Dluhy, M. J. 2010. "What Difference Does City-County Consolidation Make? A Historical Analysis of Jacksonville and Tampa, Florida." Edited by Suzanne M. Leland and Kurt M. Thurmaier. Chap. 4 in City-County Consolidation: Promises Made, Promises Kept? 83-103. Washington, DC: Georgetown University Press. 
Feiock, Richard C., and Jered B. Carr. 1997. "A Reassessment of City/County Consolidation: Economic Development Impacts." State and Local Government Review 29 (3): 166-171.

Feiock, Richard C., Jered B. Carr, and Linda S. Johnson. 2006. "Structuring the Debate on Consolidation: A Response to Leland and Thurmaier." Public Administration Review 66 (2): 274-278.

Fleischmann, Arnold. 2000. "Regionalism and City-County Consolidation in Small Metro Areas." State \& Local Government Review 32 (3): 213-226.

George, Alexander L., and Andrew Bennett. 2005. Case Studies and Theory Development in the Social Sciences. Cambridge, MA: MIT Press.

Hajnal, Zoltan, and Jessica Trounstine. 2005. "Where Turnout Matters: The Consequences of Uneven Turnout in City Politics." The Journal of Politics 67 (2): 515-535.

Hajnal, Zoltan L. 2010. America's Uneven Democracy: Race, Turnout, and Representation in City Politics. New York, NY: Cambridge University Press.

Heilig, Peggy, and Robert J. Mundt. 1983. "Changes in Representational Equity: The Effect of Adopting Districts." Social Science Quarterly 64 (2): 393.

Hyndman, Rob, George Athanasopoulos, Christoph Bergmeir, Gabriel Caceres, Leanne Chhay, Mitchell O'Hara-Wild, Fotios Petropoulos, Slava Razbash, Earo Wang, and Farah Yasmeen. 2020. forecast: Forecasting functions for time series and linear models. R package version 8.13. https://pkg. robjhyndman. com/forecast/.

Hyndman, Robert J., and Yeasmin Khandakar. 2008. "Automatic Time Series Forecasting: The forecast Package for R." Journal of Statistical Software 27 (3): 1-22. http://dx.doi.org/10.18637/jss.v027.i03.

Joint Center for Political and Economic Studies. 1970-2002. National Roster of Black Elected Officials. Washington, DC: Joint Center for Political; Economic Studies.

Karnig, Albert K. 1976. "Black Representation on City Councils: The Impact of District Elections and Socioeconomic Factors." Urban Affairs Quarterly 12 (2): 223-242.

_. 1979. "Black Resources and City Council Representation." The Journal of Politics 41 (1): 134-149.

Karnig, Albert K., and Susan Welch. 1982. "Electoral Structure and Black Representation on City Councils." Social Science Quarterly 63 (1): 99.

King, Gary, Robert O. Keohane, and Sidney Verba. 1994. Designing Social Inquiry: Scientific Inference in Qualitative Research. Princeton, NJ: Princeton University Press.

King, James D. 2002. "Single-Member Districts and the Representation of Women in American State Legislatures: The Effects of Electoral System Change." State Politics \& Policy Quarterly 2 (2): 161-175.

Leland, Susan M., and Gary A. Johnson. 2004. "Consolidation as a Local Government Reform: Why City-County Consolidation Is an Enduring Issue." Edited by Jered B. Carr and Richard C. Feiock. Chap. 2 in City-County Consolidation and Its Alternatives: Reshaping the Local Government Landscape, 25-38. Armonk, NY: M.E. Sharpe. 
Leland, Suzanne M., and Kurt M. Thurmaier. 2004. Case Studies of City-County Consolidation: Reshaping the Local Government Landscape. Armonk, NY: M.E. Sharpe.

- 2010. City-county Consolidation: Promises Made, Promises Kept? Washington, DC: Georgetown University Press.

Lewis-Beck, Michael S. 1986. "Interrupted Time Series." Edited by William D. Berry and Michael S. Lewis-Beck. In New Tools for Social Scientists: Advances and Applications in Research Methods, 209-240. Beverly Hills, CA: Sage Publications.

Lien, Pei-te, Carol Hardy-Fanta, Christine M. Sierra, Dianne M. Pinderhughes, and Lorrie A. Frasure. 2009. Concepts and Correlates of Political Representation: A Multicultural and Subnational View. Paper presented at the 2009 Annual Meeting of the Western Political Science Association.

Lyons, William E. 1977. The Politics of City-County Merger: The Lexington-Fayette County Experience. Lexington, KY: University Press of Kentucky.

MacManus, Susan A. 1978. "City Council Election Procedures and Minority Representation: Are They Related?" Social Science Quarterly 59 (1): 153-161.

Manson, Steven, Jonathan Schroeder, David Van Riper, and Steven Ruggles. 2018. IPUMS National Historical Geographic Information System: Version 13.0 [Database]. Http://doi.org/10.18128/D050.V13.0. Minneapolis, MN: University of Minnesota.

Marando, Vincent L. 1979. "City-County Consolidation: Reform, Regionalism, Referenda and Requiem." The Western Political Quarterly 32 (4): 409-421.

Martin, Lawrence L., and Jeannie Hock Schiff. 2011. "City-County Consolidations: Promise Versus Performance." State and Local Government Review 43 (2): 1-11.

Meier, Kenneth J. 1980. "Executive Reorganization of Government: Impact on Employment and Expenditures." American Journal of Political Science 24 (3): 396-412.

Morgan, David R., and Kenneth Kickham. 1999. "Changing the Form of County Government: Effects on Revenue and Expenditure Policy." Public Administration Review 59 (4): 315-324.

Morgan, David R., and John P. Pelissero. 1980. "Urban Policy: Does Political Structure Matter?" The American Political Science Review 74 (4): 999-1006.

Ostrom, Elinor. 1972. "Metropolitan Reform: Propositions Derived From Two Traditions." Social Science Quarterly 53 (3): 474-493.

Pitkin, Hanna Fenichel. 1967. The Concept of Representation. Berkeley, CA: University of California Press.

Polinard, Jerry L., Robert D. Wrinkle, Tomas Longoria, and Norman E. Binder. 1994. Electoral Structure and Urban Policy: The Impact on Mexican American Communities. Armonk, NY: M.E. Sharpe.

Robinson, Theodore P., and Thomas R. Dye. 1978. "Reformism and Black Representation on City Councils." Social Science Quarterly 59 (1): 133-141. 
Rosenbaum, Walter A., and Gladys Marie Kammerer. 1974. Against Long Odds: The Theory and Practice of Successful Governmental Consolidation. Beverly Hills, CA: Sage Publications.

Rusk, David. 2003. Cities Without Suburbs. 3rd ed. Washington, DC: Woodrow Wilson Center Press.

Savitch, Hank V., and Ronald K. Vogel. 2004a. "Louisville/Jefferson County, Kentucky." Edited by Suzanne M. Leland and Kurt M. Thurmaier. Chap. 14 in Case Studies of City-County Consolidation: Reshaping the Local Government Landscape, 272-290. Armonk, NY: M.E. Sharpe.

_. 2004b. "Suburbs Without a City: Power and City-County Consolidation." Urban Affairs Review 39 (6): 758-790.

Seamon, Fred, and Richard C. Feiock. 1995. "Political Participation and City County Consolidation: Jacksonville-Duval County." International Journal of Public Administration 18 (11): 1741-1752.

Selden, Sally Coleman, and Richard W. Campbell. 2000. "The Expenditure Impacts of Unification in a Small Georgia County: A Contingency Perspective of City-County Consolidation." Public Administration Quarterly 24 (2): 169-201.

Southern Regional Council. 1984. The Southern Regional Council Papers, 1944-1968. Ann Arbor, MI: University Microfilms.

Stoffer, David. 2020. astsa: Applied Statistical Time Series Analysis. R package version 1.12. http://www. stat.pitt.edu/stoffer/tsda/.

Swanson, Bert E. 2000. "Quandaries of Pragmatic Reform: A Reassessment of the Jacksonville Experience." State \& Local Government Review 32 (3): 227-238.

Swartz, N. J. 2010. "Does Consolidation Make a Difference? A Comparative Analysis of Richmond and Virginia Beach, Virginia." Edited by Suzanne M. Leland and Kurt M. Thurmaier. Chap. 3 in City-County Consolidation: Promises Made, Promises Kept? 57-81. Washington, DC: Georgetown University Press.

Taebel, Delbert. 1978. "Minority Representation on City Councils: The Impact of Structure on Blacks and Hispanics." Social Science Quarterly 59 (1): 142-152.

Taylor, Charles D., Dagney Faulk, and Pamela Schaal. 2017. "Where Are the Cost Savings in City-County Consolidation?" Journal of Urban Affairs 39 (2): 185-204.

Trounstine, Jessica. 2010. "Representation and Accountability in Cities." Annual Review of Political Science 13:407-423.

Trounstine, Jessica, and Melody E. Valdini. 2008. "The Context Matters: The Effects of Single-Member versus At-Large Districts on City Council Diversity." American Journal of Political Science 52 (3): 554-569.

United States Census Bureau. 2010. Statistical Abstract of the United States: 2011. 130th ed. Washington, DC: Government Printing Office. 
United States Commission on Civil Rights. 1968. Political Participation. Https://www.law.umaryland.edu/marshall/usccr/documents/cr12p753.pdf. Washington, DC: Government Printing Office.

Veiga, Francisco José, Linda Gonçalves Veiga, and Atsuyoshi Morozumi. 2017. "Political Budget Cycles and Media Freedom." Electoral Studies 45:88-99.

Weden, Margaret M., Christine E. Peterson, Jeremy N. Miles, and Regina A. Shih. 2015. "Evaluating Linearly Interpolated Intercensal Estimates of Demographic and Socioeconomic Characteristics of US Counties and Census Tracts 2001-2009." Population Research and Policy Review 34 (4): 541-559.

Welch, Susan. 1990. "The Impact of At-Large Elections on the Representation of Blacks and Hispanics." The Journal of Politics 52 (4): 1050-1076.

Welch, Susan, and Timothy Bledsoe. 1988. Urban Reform and Its Consequences: A Study in Representation. Chicago, IL: University of Chicago Press.

Yin, Robert K. 2003. Case Study Research: Design and Methods. 3rd ed. Thousand Oaks, CA: Sage Publications. 


\section{Tables \& Figures}

\section{Table 1}

Table 1. City \& County Case Comparisons (Matched Pair Criteria)

\begin{tabular}{|c|c|c|c|c|c|c|c|}
\hline $\begin{array}{c}\text { Year } \\
\text { Consolidated } \\
\end{array}$ & $\begin{array}{c}\text { County } \\
\text { Equivalent }\end{array}$ & State & Population & $\begin{array}{l}\text { Percent } \\
\text { Black }\end{array}$ & $\begin{array}{l}\text { Median } \\
\text { Income }\end{array}$ & Education & GOP Vote \\
\hline \multirow[t]{2}{*}{1968} & Duval & FL & 515,320 & $22.9 \%$ & $\$ 7,611$ & $9.4 \%$ & $50.5 \%$ \\
\hline & Palm Beach & FL & 328,421 & $18.3 \%$ & $\$ 7,771$ & $12.8 \%$ & $53.1 \%$ \\
\hline \multirow[t]{2}{*}{1968} & Ormsby & NV & 15,254 & $5.8 \%$ & $\$ 10.359$ & $56.6 \%$ & $50.5 \%$ \\
\hline & Lyon & NV & 8,204 & $6.3 \%$ & $\$ 8,355$ & $8.0 \%$ & $53.9 \%$ \\
\hline \multirow[t]{2}{*}{1970} & Juneau & AK & 13,774 & $0.8 \%$ & $\$ 30,834$ & $23.7 \%$ & $43.0 \%$ \\
\hline & Ketchikan & $\mathrm{AK}$ & 10,140 & $0.4 \%$ & $\$ 27,015$ & $15.6 \%$ & $50.0 \%$ \\
\hline \multirow[t]{2}{*}{1970} & Marion & IN & 794,197 & $17 \%$ & $\$ 9,615$ & $12 \%$ & $52.3 \%$ \\
\hline & Allen & IN & 281,344 & $6.9 \%$ & $\$ 9,911$ & $10.8 \%$ & $54.3 \%$ \\
\hline \multirow[t]{2}{*}{1971} & Sitka & AK & 6,414 & $0.6 \%$ & $\$ 31,133$ & $15.4 \%$ & $44.7 \%$ \\
\hline & Nome (Area) & AK & 5,812 & $0.4 \%$ & $\$ 14,550$ & $9.7 \%$ & $44.8 \%$ \\
\hline \multirow[t]{2}{*}{1971} & Muscogee & GA & 170,658 & $26.6 \%$ & $\$ 7,722$ & $10.7 \%$ & $32.4 \%$ \\
\hline & Bibb & GA & 145,839 & $34.8 \%$ & $\$ 7,790$ & $10 \%$ & $32.6 \%$ \\
\hline \multirow[t]{2}{*}{1974} & Suffolk & VA & 38,807 & $51.9 \%$ & $\$ 7,822$ & $7.9 \%$ & $\mathbf{5 7 . 9 \%}$ \\
\hline & King \& Queen & VA & 5,805 & $48.3 \%$ & $\$ 8,285$ & $6.6 \%$ & $58.3 \%$ \\
\hline \multirow[t]{2}{*}{1974} & Fayette & $\mathrm{KY}$ & 193,937 & $12.6 \%$ & $\$ 11,424$ & $21.4 \%$ & $66.5 \%$ \\
\hline & Woodford & $\mathrm{KY}$ & 16,195 & $9.1 \%$ & $\$ 11,452$ & $12.3 \%$ & $70.3 \%$ \\
\hline \multirow[t]{2}{*}{1975} & Anchorage & AK & 152,374 & $5.4 \%$ & $\$ 27,375$ & $17.0 \%$ & $64.7 \%$ \\
\hline & Fairbanks & $\mathrm{AK}$ & 48,481 & $5.9 \%$ & $\$ 23,647$ & $17.6 \%$ & $47.7 \%$ \\
\hline \multirow[t]{2}{*}{1977} & Deer Lodge & MT & 14,578 & $0.4 \%$ & $\$ 13,244$ & $7.5 \%$ & $35.6 \%$ \\
\hline & Hill & MT & 18,088 & $0.2 \%$ & $\$ 13,858$ & $9.2 \%$ & $45.1 \%$ \\
\hline \multirow[t]{2}{*}{1977} & Silver Bow & MT & 42,129 & $0.1 \%$ & $\$ 12,375$ & $9.1 \%$ & $39.3 \%$ \\
\hline & Flathead & MT & 46,196 & $0.1 \%$ & $\$ 13,522$ & $8.5 \%$ & $55.7 \%$ \\
\hline \multirow[t]{2}{*}{1984} & Terrebonne & LA & 100,925 & $15.8 \%$ & $\$ 20,212$ & $9.6 \%$ & $69.5 \%$ \\
\hline & Lafourche & LA & 88,606 & $11.6 \%$ & $\$ 19,301$ & $9.8 \%$ & $65.4 \%$ \\
\hline \multirow[t]{2}{*}{1988} & Moore & $\mathrm{TN}$ & 4,786 & $3.8 \%$ & $\$ 25,376$ & $9.6 \%$ & $51.4 \%$ \\
\hline & Smith & $\mathrm{TN}$ & 14,070 & $3.4 \%$ & $\$ 21,394$ & $6.5 \%$ & $45.6 \%$ \\
\hline \multirow[t]{2}{*}{1991} & Clarke & GA & 87,997 & $26.7 \%$ & $\$ 21,566$ & $37.7 \%$ & $49.7 \%$ \\
\hline & Ware & GA & 35,521 & $26.3 \%$ & $\$ 21,219$ & $10.4 \%$ & $52.6 \%$ \\
\hline \multirow[t]{2}{*}{1996} & Lafayette & LA & 181,402 & $23.9 \%$ & $\$ 31,646$ & $24.2 \%$ & $48.9 \%$ \\
\hline & Ouachita & LA & 146,693 & $32.7 \%$ & $\$ 27,680$ & $21.1 \%$ & $49.6 \%$ \\
\hline \multirow[t]{2}{*}{1996} & Richmond & GA & 192,397 & $44.7 \%$ & $\$ 29,958$ & $18.1 \%$ & $41.6 \%$ \\
\hline & Chatham & GA & 225,423 & $41.2 \%$ & $\$ 33,340$ & $22.5 \%$ & $44.9 \%$ \\
\hline \multirow[t]{2}{*}{1998} & Wyandotte & KS & 152,521 & $27.8 \%$ & $\$ 31,783$ & $11.7 \%$ & $28.2 \%$ \\
\hline & Geary & KS & 25,226 & $21.9 \%$ & $\$ 29,915$ & $16.6 \%$ & $54.3 \%$ \\
\hline \multirow[t]{2}{*}{2001} & Trousdale & TN & 7,350 & $10.9 \%$ & $\$ 32,573$ & $9.2 \%$ & $32.3 \%$ \\
\hline & Giles & $\mathrm{TN}$ & 29,613 & $11.7 \%$ & $\$ 34,888$ & $10.8 \%$ & $43.5 \%$ \\
\hline \multirow[t]{2}{*}{2002} & Haines & AK & 2,414 & $0.2 \%$ & $\$ 42,565$ & $25.5 \%$ & $53.3 \%$ \\
\hline & Lake \& Peninsula & $\mathrm{AK}$ & 1,787 & $0.1 \%$ & $\$ 38,982$ & $13.3 \%$ & $54.4 \%$ \\
\hline
\end{tabular}

Note. Racial data prior to 1970 is the percentage of Non-Whites. Consolidated governments are shown in bold. 


\section{Table 2}

Table 2. Factors Impacting Equity in African-American Representation

\begin{tabular}{|c|c|c|c|}
\hline & \multicolumn{3}{|c|}{ Dependent Variable: Equity Ratio } \\
\hline & Model 1 & Model 2 & Model 3 \\
\hline Time & $\begin{array}{c}0.022^{* * *} \\
(0.002)\end{array}$ & $\begin{array}{c}0.001 \\
(0.005)\end{array}$ & $\begin{array}{c}0.000 \\
(0.005)\end{array}$ \\
\hline Post-Consolidation (Dummy) & $\begin{array}{c}0.257 \\
(0.220)\end{array}$ & $\begin{array}{c}0.068 \\
(0.059)\end{array}$ & $\begin{array}{c}0.113 \\
(0.061)\end{array}$ \\
\hline Time $\times$ Post-Consolidation & $\begin{array}{c}-0.014 \\
(0.008)\end{array}$ & $\begin{array}{c}-0.017^{* * *} \\
(0.002)\end{array}$ & $\begin{array}{c}-0.019^{* * *} \\
(0.003)\end{array}$ \\
\hline VRA Preclearance (Dummy) & $\begin{array}{c}-0.029 \\
(0.048)\end{array}$ & $\begin{array}{c}-0.445^{* * *} \\
(0.049)\end{array}$ & $\begin{array}{c}-0.461^{* * *} \\
(0.052)\end{array}$ \\
\hline VRA $\times$ Consolidated Government & $\begin{array}{c}0.262^{* * *} \\
(0.049)\end{array}$ & $\begin{array}{c}0.084 \\
(0.038)\end{array}$ & $\begin{array}{c}0.100^{*} \\
(0.042)\end{array}$ \\
\hline Population (log) & & $\begin{array}{c}0.100^{* * *} \\
(0.008)\end{array}$ & $\begin{array}{c}0.112^{* * *} \\
(0.009)\end{array}$ \\
\hline$\%$ Black & & $\begin{array}{c}2.197^{* * *} \\
(0.113)\end{array}$ & $\begin{array}{c}2.223^{* * *} \\
(0.123)\end{array}$ \\
\hline \% College Degree & & $\begin{array}{c}1.359^{* * *} \\
(0.176)\end{array}$ & $\begin{array}{c}1.578^{* * *} \\
(0.173)\end{array}$ \\
\hline Median Household Income ( $\$ 10 \mathrm{k})$ & & $\begin{array}{l}0.014^{* *} \\
(0.005)\end{array}$ & $\begin{array}{l}0.014^{* *} \\
(0.005)\end{array}$ \\
\hline GOP Vote Share & & $\begin{array}{c}0.203^{* * *} \\
(0.061)\end{array}$ & $\begin{array}{c}0.201^{* * *} \\
(0.060)\end{array}$ \\
\hline Consolidated 1970s (Dummy) & & & $\begin{array}{c}0.255^{* * *} \\
(0.017)\end{array}$ \\
\hline Consolidated 1980s (Dummy) & & & $\begin{array}{c}0.389^{* * *} \\
(0.031)\end{array}$ \\
\hline Consolidated 1990s (Dummy) & & & $\begin{array}{c}0.167^{* * *} \\
(0.026)\end{array}$ \\
\hline Consolidated 2000s (Dummy) & & & $\begin{array}{c}0.156^{* * *} \\
(0.044)\end{array}$ \\
\hline Constant & $\begin{array}{l}0.108^{*} \\
(0.048)\end{array}$ & $\begin{array}{c}-1.194^{* * *} \\
(0.082)\end{array}$ & $\begin{array}{c}-1.556^{* * *} \\
(0.010) \\
\end{array}$ \\
\hline Observations & 1,444 & 1,105 & 1,105 \\
\hline $\mathrm{R}^{2}$ & 0.047 & 0.374 & 0.393 \\
\hline
\end{tabular}

Note. Panel-corrected standard errors shown in parentheses. ${ }^{*} \mathrm{p}<0.05 ;{ }^{* *} \mathrm{p}<0.01 ;{ }^{* * *} \mathrm{p}<0.001$. 


\section{Figure 1}

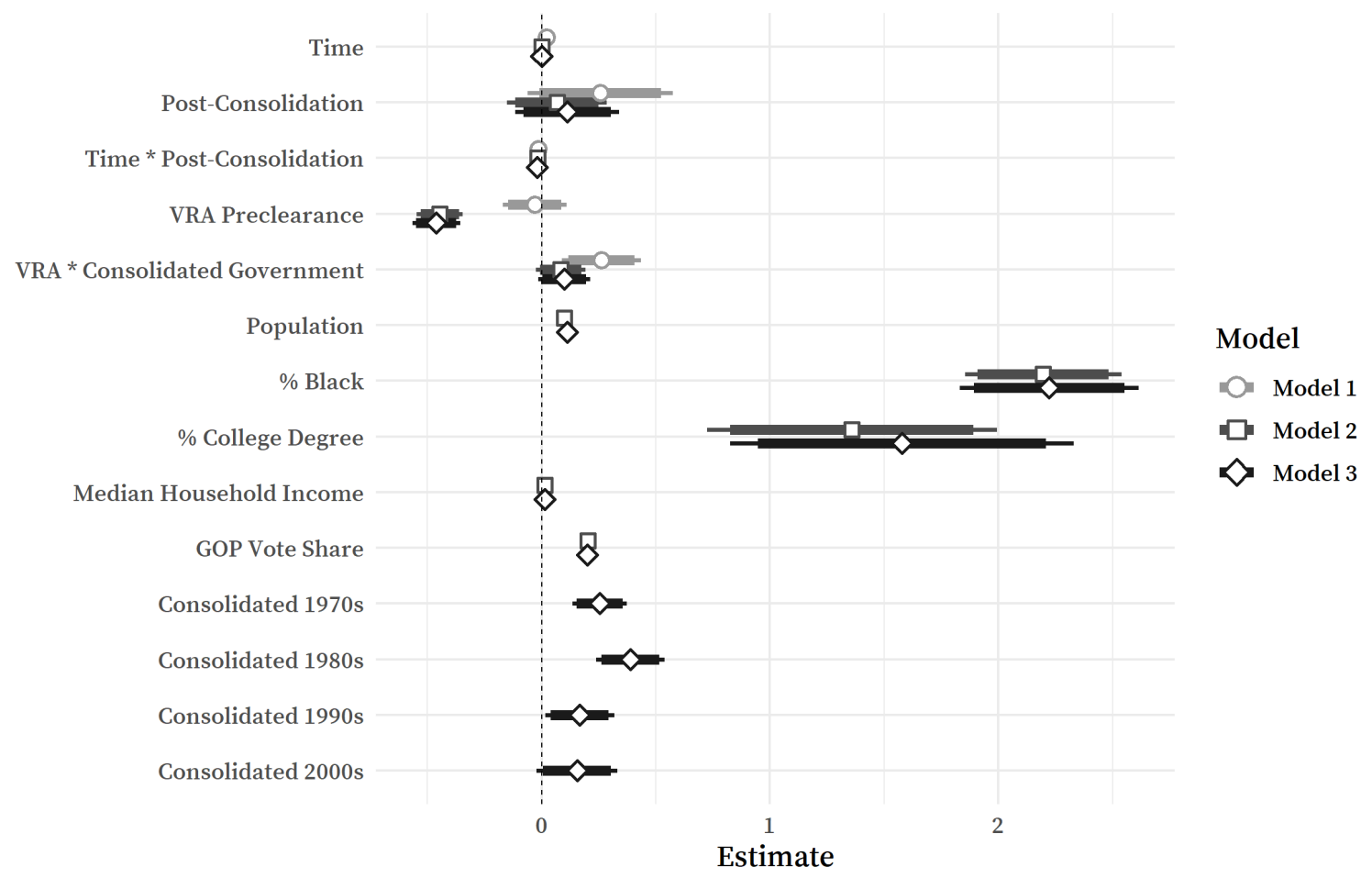

Figure 1. Forest plot comparing Models 1-3 (with 90\% \& 95\% confidence intervals). Note. Thick bars show $90 \%$ confidence intervals; thin bars show $95 \%$ confidence intervals. 


\section{Figure 2}

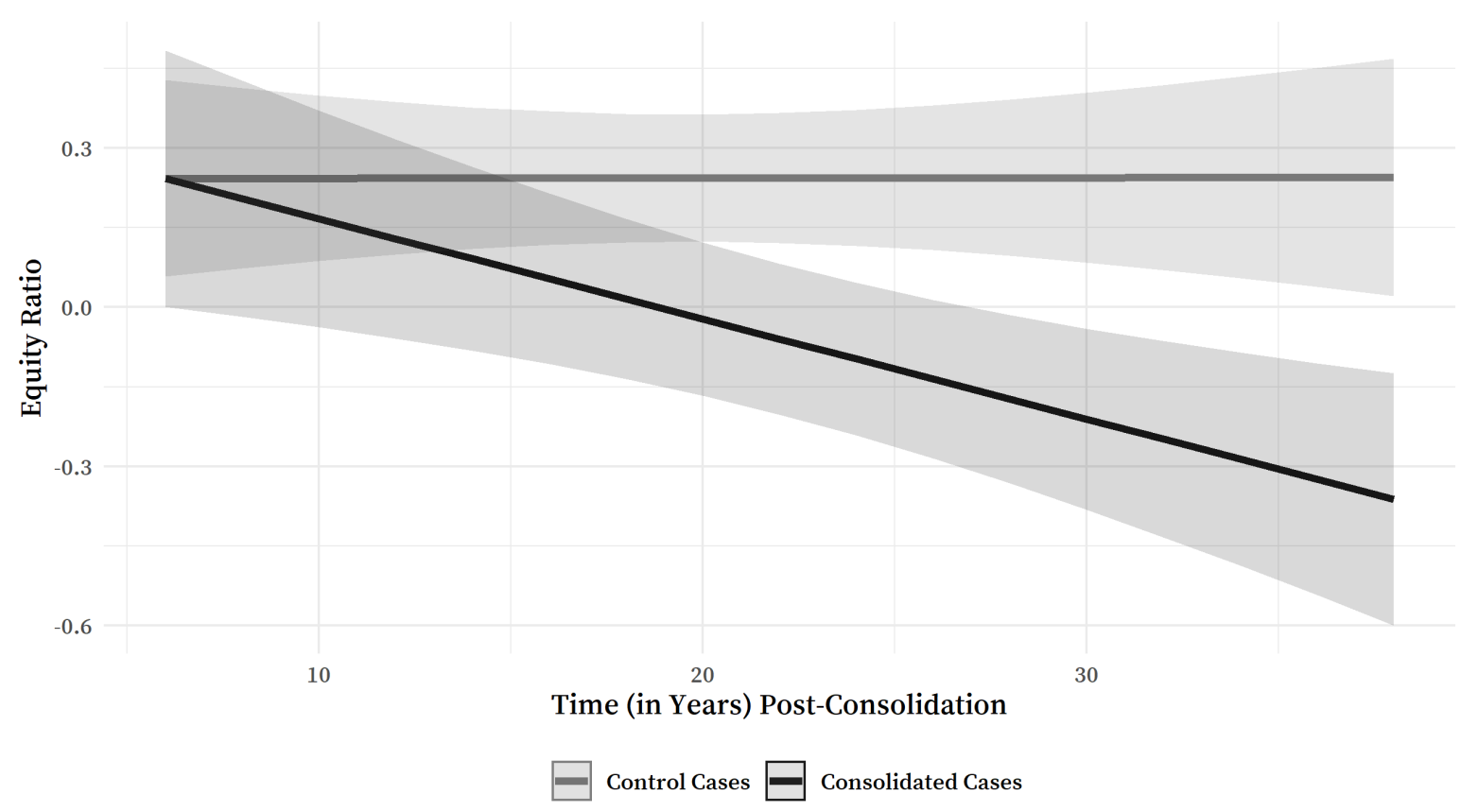

Figure 2. Marginal effect of consolidation over time.

Note. Shaded areas represent $95 \%$ confidence intervals. 


\section{Figure 3}

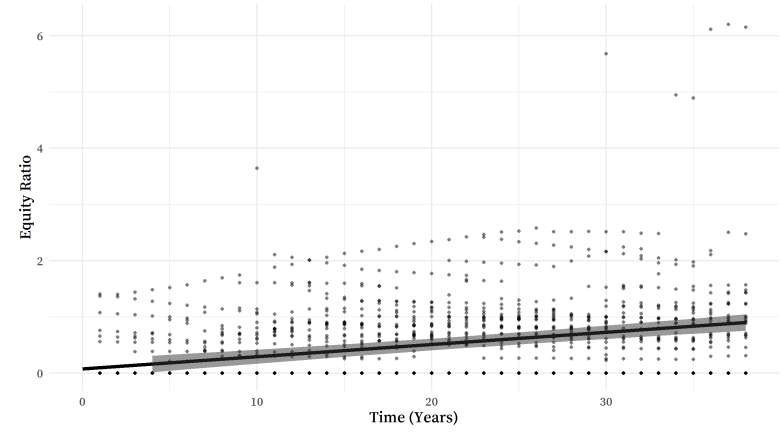

(a) Time-series (Model 1)

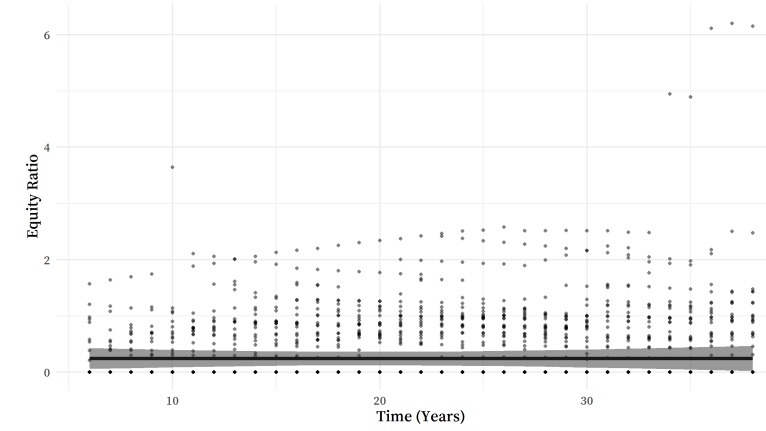

(b) Time-series (Model 3)

Figure 3. Predicted equity ratios over time: Models 1 \& 3 . 
Figure 4

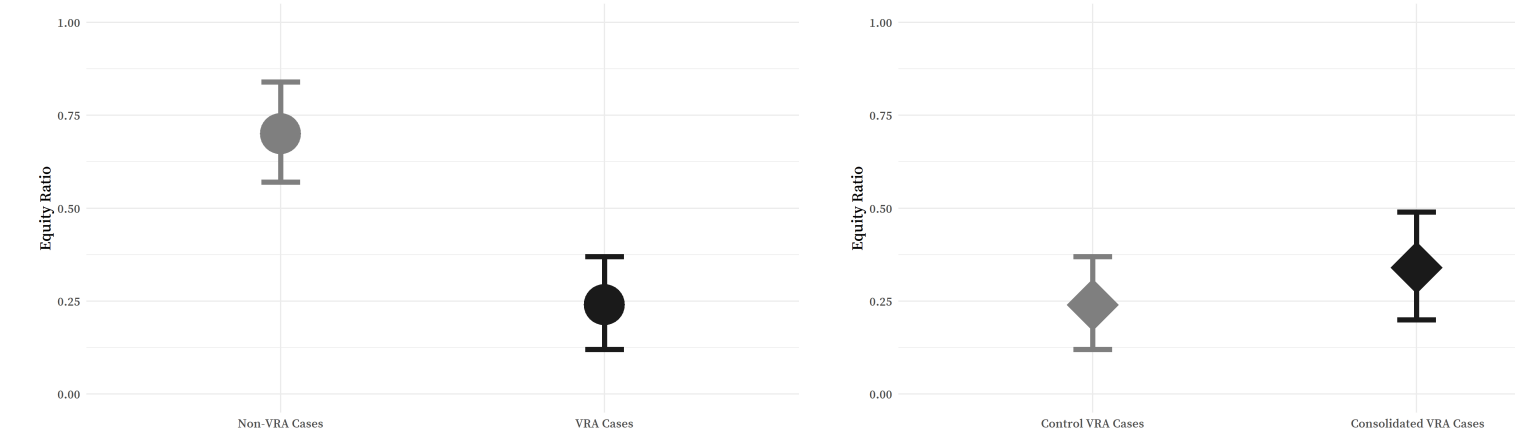

(a) VRA preclearance \& non-preclearnace cases. (b) VRA cases: Consolidated \& non-consolidated.

Figure 4. Predicted equity ratios (Model 3): Consolidation \& Voting Rights Act cases. 


\section{Supplementary Materials}

\section{Individual County Models}

Shown below are the individual models for each consolidated and comparison county. Included are both linear and ARIMA models, along with their associated tests for comparison. Linear models are presented using the basic model used for the full panel, with the omission of the VRA variables (thus, taking on a basic difference-in-differences equation, with Time, the Consolidation dummy variable, and the interaction of the two). ARIMA models are presented similar to Feiock and Carr (1997), Carr and Feiock (1999), and Carr, Bae, and $\mathrm{Lu}$ (2006), including coefficients, t-values, and associated tests, including unit root tests, such as the Augmented Dickey-Fuller and Ljung-Box tests. The best fit for each ARIMA model was achieved with the assistance of the astsa package (Stoffer 2020) and the forecast package (Hyndman and Khandakar 2008; Hyndman et al. 2020) in R.

In all, of the included models, those with lower Akaike Information Criterion (AIC) and Bayesian Information Criterion (BIC) values were roughly split between the linear and ARIMA models. In comparing AIC and BIC of each model, linear models show lower values in 23 of the 50 reported measures, compared to 27 with the ARIMA models, indicating that the ARIMA models could be a "better" fit in slightly more than half the cases. Four pairs of consolidated and control cases ${ }^{9}$ were excluded from the results below, due to the fact that neither of the matched pairs had a single Black elected official within the specified time frame; thus, no estimates could be calculated for either the linear or ARIMA models.

As the ARIMA models demonstrate, 14 of the counties show a significant year-to-year change in representational equity (12 positive; two negative), while only nine demonstrate a significant change after the consolidation period (seven increases in the equity ratio, and two decreases). Linear models show similar mixed results when examining the change in the equity ratio over time, post-consolidation, and the interaction term between these two variables. All of the statistically significant changes in Time (15 total) are positive among both consolidated and control group cases; however, results are split when it comes to the post-consolidation period (Consolidation) and the interaction term. Seven of the consolidated and four control cases show a significant increase in the equity ratio post-consolidation, while two consolidated cases show a decrease in the intercept during the same period. However, when examining the interaction of Time and Consolidation, only one (1) consolidation case shows a positive increase post-consolidation, while four consolidated cases and three control cases show a significant decrease in the equity ratio. 
Duval \& Palm Beach Counties, Florida (Consolidated 1968; VRA Preclearance) Linear Model

\begin{tabular}{lcc}
\hline & Duval & Palm Beach \\
\hline (Intercept) & -0.437 & 0.000 \\
Time & $(0.306)$ & $(0.323)$ \\
& $0.327^{*}$ & 0.000 \\
Consolidation & $(0.142)$ & $(0.150)$ \\
& $1.171^{* * *}$ & -0.257 \\
Time $\times$ Consolidation & $(0.316)$ & $(0.334)$ \\
& $-0.324^{*}$ & 0.039 \\
Num.Obs. & $(0.142)$ & $(0.150)$ \\
R2 & 38 & 38 \\
R2 Adj. & 0.464 & 0.806 \\
AIC & 0.417 & 0.788 \\
BIC & -8.6 & -4.4 \\
Log.Lik. & -0.4 & 3.8 \\
F & 9.285 & 7.217 \\
\hline$* \mathrm{p}<0.05, * * \mathrm{p}<0.01, * * * \mathrm{p}<0.001$
\end{tabular}

ARIMA Model

\begin{tabular}{lcc}
\hline & Duval & Palm Beach \\
\hline Constant & 0.674 & 0.008 \\
& $(3.706)$ & $(0.048)$
\end{tabular}

Consolidation

0.384

0

\begin{tabular}{lcc} 
& $(1.966)$ & $(0)$ \\
\hline Model $(p, d, q)$ & $(0,0,3)$ & $(0,1,0)$
\end{tabular}

AIC

BIC

$-20.02$

$-10.19$

$-4.2$

$\mathrm{ADF}$

$-3.045$

ADF (p-value)

0.165

2.23

$-4.237$

Ljung-Box (Q-Stat)

2.32

0.011

Note: t-values shown in parentheses.

$* \mathrm{p}<0.05, * * \mathrm{p}<0.01, * * * \mathrm{p}<0.001$

Juneau \& Ketchican Boroughs, Alaska (Consolidated 1970; VRA Preclearance)

\section{Linear Model}

\begin{tabular}{lcc}
\hline & Juneau & Ketchican \\
\hline (Intercept) & 0.000 & $0.000 \mathrm{NA}$ \\
& $(4.924)$ & $(0.000)$ \\
Time & 0.000 & $0.000 \mathrm{NA}$ \\
& $(1.484)$ & $(0.000)$ \\
Consolidation & 0.363 & $0.000 \mathrm{NA}$ \\
& $(5.336)$ & $(0.000)$ \\
Time $\times$ Consolidation & 0.116 & $0.000 \mathrm{NA}$ \\
& $(1.487)$ & $(0.000)$ \\
\hline Num.Obs. & 38 & 38 \\
R2 & 0.094 & \\
R2 Adj. & 0.014 & \\
AIC & 231.1 & \\
BIC & 239.3 & \\
Log.Lik. & -110.568 \\
$\mathrm{~F}$ & 1.175 \\
\hline$* \mathrm{p}<0.05, * * \mathrm{p}<0.01, * * * \mathrm{p}<0.001$
\end{tabular}

\section{ARIMA Model}

\begin{tabular}{lcc}
\hline & Juneau & Ketchican \\
\hline Constant & 0.839 & $\mathrm{n} / \mathrm{a}$ \\
& $(9.784)$ & $\mathrm{n} / \mathrm{a}$ \\
Consolidation & 1.372 & $\mathrm{n} / \mathrm{a}$ \\
& $(0.691)$ & $\mathrm{n} / \mathrm{a}$ \\
\hline Model $(p, d, q)$ & $(1,0,0)$ & $(0,0,0)$ \\
AIC & 183.59 & $\mathrm{n} / \mathrm{a}$ \\
BIC & 188.51 & $\mathrm{n} / \mathrm{a}$ \\
ADF & -1.598 & $\mathrm{n} / \mathrm{a}$ \\
ADF (p-value) & 0.73 & $\mathrm{n} / \mathrm{a}$ \\
Ljung-Box $(\mathrm{Q}-$ Stat $)$ & 5.22 & 0 \\
\hline Note: t-values shown in parentheses. \\
$* \mathrm{p}<0.05, * * \mathrm{p}<0.01, * * \mathrm{p}<0.001$
\end{tabular}


Marion \& Allen Counties, Indiana (Consolidated 1970; No VRA Preclearance) Linear Model

\begin{tabular}{lcc}
\hline & Marion & Allen \\
\hline (Intercept) & $1.095^{* * *}$ & $1.444^{* *}$ \\
Time & $(0.121)$ & $(0.444)$ \\
& -0.020 & -0.041 \\
Consolidation & $(0.031)$ & $(0.134)$ \\
& $-0.311^{*}$ & 0.142 \\
Time $\times$ Consolidation & $(0.135)$ & $(0.481)$ \\
& 0.031 & 0.035 \\
Num.Obs. & $(0.031)$ & $(0.134)$ \\
R2 & 38 & 38 \\
R2 Adj. & 0.396 & 0.033 \\
AIC & 0.343 & -0.053 \\
BIC & -41.7 & 48.3 \\
Log.Lik. & -33.5 & 56.4 \\
$\mathrm{~F}$ & 25.864 & -19.129 \\
& 7.435 & 0.381 \\
\hline$* \mathrm{p}<0.05, * * \mathrm{p}<0.01, * * * \mathrm{p}<0.001$
\end{tabular}

ARIMA Model

\begin{tabular}{lcc}
\hline & Marion & Allen \\
\hline Constant & 0.377 & 0.73 \\
& $(2.481)$ & $(6.997)$ \\
Consolidation & -0.514 & 0.017 \\
& $(-4.922)$ & $(0.07)$ \\
\hline Model $(p, d, q)$ & $(0,1,3)$ & $(1,0,0)$ \\
AIC & -47.48 & 17.05 \\
BIC & -39.43 & 23.6 \\
ADF & -2.768 & -2.058 \\
ADF (p-value) & 0.273 & 0.551 \\
Ljung-Box $(\mathrm{Q}-S t a t)$ & 7.1 & 4.02 \\
\hline Note: t-values shown in parentheses. \\
$* \mathrm{p}<0.05, * * \mathrm{p}<0.01, * * * \mathrm{p}<0.001$
\end{tabular}

Muscogee \& Bibb Counties, Georgia (Consolidated 1971; VRA Preclearance) Linear Model

\begin{tabular}{lcc}
\hline & Muscogee & Bibb \\
\hline (Intercept) & 0.000 & 0.000 \\
& $(0.111)$ & $(0.345)$ \\
Time & 0.000 & 0.000 \\
& $(0.028)$ & $(0.089)$ \\
Consolidation & $0.602 * * *$ & -0.027 \\
& $(0.124)$ & $(0.386)$ \\
Time $\times$ Consolidation & 0.007 & 0.070 \\
& $(0.029)$ & $(0.089)$ \\
\hline Num.Obs. & 38 & 38 \\
R2 & 0.866 & 0.845 \\
R2 Adj. & 0.854 & 0.831 \\
AIC & -48.1 & 38.1 \\
BIC & -39.9 & 46.3 \\
Log.Lik. & 29.034 & -14.062 \\
F & 73.182 & 61.772 \\
\hline$* \mathrm{p}<0.05, * * \mathrm{p}<0.01, * * * \mathrm{p}<0.001$
\end{tabular}

ARIMA Model

\begin{tabular}{lcc}
\hline & Muscogee & Bibb \\
\hline Constant & 0.568 & 0.069 \\
Consolidation & $(2.112)$ & $(1.642)$ \\
& 0.748 & -0.069 \\
& $(5.683)$ & $(-0.27)$ \\
\hline Model $(p, d, q)$ & $(1,1,1)$ & $(0,1,0)$ \\
AIC & -49.33 & 8.88 \\
BIC & -42.89 & 13.71 \\
ADF & -1.924 & -1.861 \\
ADF (p-value) & 0.603 & 0.628 \\
Ljung-Box (Q-Stat) & 8.04 & 8.27 \\
\hline Note: t-values shown in parentheses. \\
* p $<0.05, * * \mathrm{p}<0.01, * * * \mathrm{p}<0.001$
\end{tabular}


Suffolk \& King and Queen Counties, Virginia (Consolidated 1974; VRA Preclearance) Linear Model

\begin{tabular}{|c|c|c|c|c|c|}
\hline \multirow[b]{2}{*}{ (Intercept) } & \multirow{2}{*}{$\begin{array}{c}\text { Suffolk } \\
0.073 \\
(0.184)\end{array}$} & \multirow{2}{*}{$\begin{array}{c}\text { King \& Queen } \\
0.000 \\
(0.199)\end{array}$} & \multicolumn{3}{|c|}{ ARIMA Model } \\
\hline & & & & Suffolk & King \& Queen \\
\hline Time & $\begin{array}{c}0.045 \\
(0.033)\end{array}$ & $\begin{array}{c}0.000 \\
(0.035)\end{array}$ & Constant & $\begin{array}{c}0.834 \\
(7.991)\end{array}$ & $\begin{array}{c}0.719 \\
(6.399)\end{array}$ \\
\hline Consolidation & $\begin{array}{c}0.094 \\
(0.233)\end{array}$ & $\begin{array}{l}-0.168 \\
(0.252)\end{array}$ & Consolidation & $\begin{array}{c}0.131 \\
(0.679)\end{array}$ & $\begin{array}{l}0.15 \\
(1.3)\end{array}$ \\
\hline Time $\times$ Consolidation & $\begin{array}{l}-0.024 \\
(0.033)\end{array}$ & $\begin{array}{c}0.016 \\
(0.036) \\
\end{array}$ & $\begin{array}{l}\text { Model }(p, d, q) \\
\text { AIC }\end{array}$ & $\begin{array}{c}(1,0,0) \\
-13.97\end{array}$ & $\begin{array}{c}(1,0,0) \\
-9.34\end{array}$ \\
\hline Num.Obs. & 38 & 38 & $\mathrm{BIC}$ & -7.42 & -4.42 \\
\hline $\mathrm{R} 2$ & 0.474 & 0.241 & $\mathrm{ADF}$ & -3.281 & -3.077 \\
\hline R2 Adj. & 0.428 & 0.174 & ADF (p-value) & 0.09 & 0.153 \\
\hline AIC & 9.2 & 15.2 & Ljung-Box (Q-Stat) & 5.22 & $12.44^{*}$ \\
\hline $\begin{array}{l}\text { BIC } \\
\text { Log.Lik. } \\
\text { F }\end{array}$ & $\begin{array}{c}17.4 \\
0.390 \\
10.217\end{array}$ & $\begin{array}{c}23.4 \\
-2.611 \\
3.607\end{array}$ & \multicolumn{3}{|c|}{$\begin{array}{l}\text { Note: } \mathrm{t} \text {-values shown in parentheses. } \\
{ }^{*} \mathrm{p}<0.05,{ }^{* *} \mathrm{p}<0.01, * * * \mathrm{p}<0.001\end{array}$} \\
\hline
\end{tabular}

Fayette \& Woodford Counties, Kentucky (Consolidated 1974; No VRA Preclearance)

\begin{tabular}{lcc}
\hline & Fayette & Woodford \\
\hline (Intercept) & $0.680^{* * *}$ & $1.301^{*}$ \\
Time & $(0.153)$ & $(0.638)$ \\
& -0.039 & 0.048 \\
Consolidation & $(0.027)$ & $(0.113)$ \\
& $0.395^{*}$ & -0.881 \\
Time $\times$ Consolidation & $(0.194)$ & $(0.807)$ \\
& 0.035 & 0.058 \\
Num.Obs. & $(0.028)$ & $(0.115)$ \\
R2 & 38 & 38 \\
R2 Adj. & 0.549 & 0.582 \\
AIC & 0.509 & 0.545 \\
BIC & -4.7 & 103.7 \\
Log.Lik. & 3.5 & 111.9 \\
F & 7.368 & -46.846 \\
\hline$* \mathrm{p}<0.05, * * \mathrm{p}<0.01, * * * \mathrm{p}<0.001$ & 15.772 \\
\hline
\end{tabular}

ARIMA Model

\begin{tabular}{lcc}
\hline & Fayette & Woodford \\
\hline Constant & 0.289 & -0.13 \\
& $(1.987)$ & $(-0.895)$ \\
Consolidation & 0.477 & 1.897 \\
& $(8.08)$ & $(3.525)$ \\
\hline Model $(p, d, q)$ & $(3,0,0)$ & $(0,1,0)$ \\
AIC & -14.56 & 63.15 \\
BIC & -4.73 & 66.37 \\
ADF & -3.359 & -1.151 \\
ADF (p-value) & 0.078 & 0.902 \\
Ljung-Box (Q-Stat) & 3.76 & 2.51 \\
\hline Note: t-values shown in parentheses. \\
* p $<0.05, * * \mathrm{p}<0.01, * * * \mathrm{p}<0.001$
\end{tabular}


Anchorage \& Fairbanks Boroughs, Alaska (Consolidated 1975; VRA Preclearance) Linear Model

\begin{tabular}{|c|c|c|c|c|c|}
\hline \multirow[b]{2}{*}{ (Intercept) } & \multirow{2}{*}{$\begin{array}{c}\text { Anchorage } \\
0.000 \\
(0.269)\end{array}$} & \multirow{2}{*}{$\begin{array}{c}\text { Fairbanks } \\
-0.536 \\
(0.337)\end{array}$} & \multicolumn{3}{|c|}{ ARIMA Model } \\
\hline & & & & Anchorage & Fairbanks \\
\hline Time & $\begin{array}{c}0.000 \\
(0.043)\end{array}$ & $\begin{array}{l}0.156 * * \\
(0.054)\end{array}$ & Constant & $\begin{array}{c}0.01 \\
(0.06)\end{array}$ & $\begin{array}{c}0.16 \\
(0.928)\end{array}$ \\
\hline Consolidation & $\begin{array}{l}-0.781^{*} \\
(0.359)\end{array}$ & $\begin{array}{c}2.883^{* \cdots *} \\
(0.450)\end{array}$ & Consolidation & $\begin{array}{c}0 \\
(0)\end{array}$ & $\begin{array}{c}-0.002 \\
(-0.005)\end{array}$ \\
\hline Time $\times$ Consolidation & $\begin{array}{c}0.041 \\
(0.044)\end{array}$ & $\begin{array}{c}-0.224 * * * \\
(0.056)\end{array}$ & $\begin{array}{l}\text { Model }(p, d, q) \\
\text { AIC }\end{array}$ & $\begin{array}{l}(0,1,0) \\
10.14\end{array}$ & $\begin{array}{c}(0,1,0) \\
44.86\end{array}$ \\
\hline Num.Obs. & 38 & 38 & BIC & 14.25 & 49.7 \\
\hline $\mathrm{R} 2$ & 0.395 & 0.578 & $\mathrm{ADF}$ & -0.72 & -2.83 \\
\hline R2 Adj. & 0.341 & 0.541 & ADF (p-value) & 0.96 & 0.249 \\
\hline AIC & 42.7 & 60.0 & Ljung-Box (Q-Stat) & 0.09 & 6.43 \\
\hline $\begin{array}{l}\text { BIC } \\
\text { Log.Lik. } \\
\text { F }\end{array}$ & $\begin{array}{c}50.9 \\
-16.350 \\
7.394\end{array}$ & $\begin{array}{c}68.2 \\
-24.998 \\
15.544\end{array}$ & \multicolumn{3}{|c|}{$\begin{array}{l}\text { Note: } \mathrm{t} \text {-values shown in parentheses. } \\
* \mathrm{p}<0.05, * * \mathrm{p}<0.01, * * * \mathrm{p}<0.001\end{array}$} \\
\hline
\end{tabular}

Terrebonne \& Lafourche Parishes, Louisiana (Consolidated 1984; VRA Preclearance) Linear Model

\begin{tabular}{lcc}
\hline & Terrebonne & Lafourche \\
\hline (Intercept) & $-0.427^{* *}$ & 0.000 \\
& $(0.134)$ & $(0.036)$ \\
Time & $0.077^{* * *}$ & 0.000 \\
& $(0.012)$ & $(0.003)$ \\
Consolidation & $2.173^{* * *}$ & $0.305^{* *}$ \\
& $(0.372)$ & $(0.101)$ \\
Time $\times$ Consolidation & $-0.107^{* * *}$ & 0.005 \\
& $(0.017)$ & $(0.005)$ \\
\hline Num.Obs. & 38 & 38 \\
R2 & 0.705 & 0.902 \\
R2 Adj. & 0.679 & 0.893 \\
AIC & 17.1 & -81.9 \\
BIC & 25.3 & -73.7 \\
Log.Lik. & -3.540 & 45.927 \\
F & 27.058 & 104.083 \\
\hline$* \mathrm{p}<0.05, * * \mathrm{p}<0.01, * * * \mathrm{p}<0.001$
\end{tabular}

ARIMA Model

\begin{tabular}{lcc}
\hline & Terrebonne & Lafourche \\
\hline Constant & 0.936 & -0.071 \\
Consolidation & $(18.379)$ & $(-0.388)$ \\
& 0.091 & 0.437 \\
& $(0.367)$ & $(25.526)$ \\
\hline Model $(p, d, q)$ & $(1,0,0)$ & $(0,0,1)$ \\
AIC & 3.8 & -85.68 \\
BIC & 8.72 & -82.41 \\
ADF & -2.014 & -2.081 \\
ADF (p-value) & 0.568 & 0.542 \\
Ljung-Box $(\mathrm{Q}-$ Stat $)$ & 7.13 & 1.3 \\
\hline Note: t-values shown in parentheses. \\
$* \mathrm{p}<0.05, * * \mathrm{p}<0.01, * * * \mathrm{p}<0.001$
\end{tabular}


Moore \& Smith Counties, Tennessee (Consolidated 1988; No VRA Preclearance) Linear Model

\begin{tabular}{lcc}
\hline & Moore & Smith \\
\hline Intercept) & $0.000 \mathrm{NA}$ & -0.038 \\
& $(0.000)$ & $(0.091)$ \\
Time & $0.000 \mathrm{NA}$ & $0.050^{* * *}$ \\
& $(0.000)$ & $(0.007)$ \\
Consolidation & $0.000 \mathrm{NA}$ & $3.495^{* * *}$ \\
& $(0.000)$ & $(0.404)$ \\
Time $\times$ Consolidation & $0.000 \mathrm{NA}$ & $-0.143^{* * *}$ \\
& $(0.000)$ & $(0.014)$ \\
\hline Num.Obs. & 38 & 38 \\
R2 & & 0.765 \\
R2 Adj. & & 0.745 \\
AIC & & -4.8 \\
BIC & & 3.4 \\
Log.Lik. & & 7.395 \\
F & & 36.979 \\
\hline$* \mathrm{p}<0.05, * * \mathrm{p}<0.01, * * * \mathrm{p}<0.001$
\end{tabular}

ARIMA Model

\begin{tabular}{lcc}
\hline & Moore & Smith \\
\hline Constant & $\mathrm{n} / \mathrm{a}$ & 0.947 \\
& $\mathrm{n} / \mathrm{a}$ & $(24.853)$ \\
Consolidation & $\mathrm{n} / \mathrm{a}$ & 0.04 \\
& $\mathrm{n} / \mathrm{a}$ & $(0.219)$ \\
\hline Model $(p, d, q)$ & $(0,0,0)$ & $(1,0,0)$ \\
AIC & $\mathrm{n} / \mathrm{a}$ & -13.37 \\
BIC & $\mathrm{n} / \mathrm{a}$ & -8.46 \\
ADF & $\mathrm{n} / \mathrm{a}$ & -0.977 \\
ADF (p-value) & $\mathrm{n} / \mathrm{a}$ & 0.928 \\
Ljung-Box $(\mathrm{Q}-$ Stat) & 0 & 1.14 \\
\hline Note: $\mathrm{t}$-values shown in parentheses. \\
$* \mathrm{p}<0.05, * * \mathrm{p}<0.01, * * * \mathrm{p}<0.001$
\end{tabular}

Clarke \& Ware Counties, Georgia (Consolidated 1991; VRA Preclearance) Linear Model

\begin{tabular}{lcc}
\hline & Clarke & Ware \\
\hline (Intercept) & -0.094 & $-0.486^{* *}$ \\
Time & $(0.072)$ & $(0.137)$ \\
& $0.053^{* * *}$ & $0.095^{* * *}$ \\
Consolidation & $(0.005)$ & $(0.009)$ \\
& $1.349^{* *}$ & $5.092^{* * *}$ \\
Time $\times$ Consolidation & $(0.492)$ & $(0.939)$ \\
& $-0.070^{* * *}$ & $-0.177^{* * *}$ \\
\hline Num.Obs. & $(0.016)$ & $(0.030)$ \\
R2 & 38 & 38 \\
R2 Adj. & 0.796 & 0.865 \\
AIC & 0.778 & 0.853 \\
BIC & -17.5 & 31.6 \\
Log.Lik. & -9.3 & 39.8 \\
F & 13.737 & -10.803 \\
\hline$* \mathrm{p}<0.05, * * \mathrm{p}<0.01, * * * \mathrm{p}<0.001$
\end{tabular}

ARIMA Model

\begin{tabular}{lcc}
\hline & Clarke & Ware \\
\hline Constant & 0.752 & -0.045 \\
Consolidation & $(4.606)$ & $(-0.275)$ \\
& -0.432 & -0.036 \\
& $(-5.261)$ & $(-0.111)$ \\
\hline Model $(p, d, q)$ & $(0,1,2)$ & $(1,1,0)$ \\
AIC & -67.67 & 28.77 \\
BIC & -61.23 & 33.61 \\
ADF & -1.591 & -1.13 \\
ADF (p-value) & 0.733 & 0.905 \\
Ljung-Box $(\mathrm{Q}-$ Stat $)$ & 1.62 & 4.02 \\
\hline Note: t-values shown in parentheses. \\
$* \mathrm{p}<0.05, * * \mathrm{p}<0.01, * * \mathrm{p}<0.001$
\end{tabular}


Lafayette \& Ouachita Parishes, Louisiana (Consolidated 1996; VRA Preclearance) Linear Model

\begin{tabular}{lcc}
\hline & Lafayette & Ouachita \\
\hline (Intercept) & 0.128 & $-0.245^{*}$ \\
Time & $(0.132)$ & $(0.097)$ \\
& $0.024^{* *}$ & $0.056^{* * *}$ \\
Consolidation & $(0.007)$ & $(0.005)$ \\
& -0.128 & 3.170 \\
Time $\times$ Consolidation & $(2.386)$ & $(1.744)$ \\
& -0.024 & -0.100 \\
Num.Obs. & $(0.068)$ & $(0.050)$ \\
R2 & 38 & 38 \\
R2 Adj. & 0.398 & 0.824 \\
AIC & 0.344 & 0.808 \\
BIC & 35.9 & 12.0 \\
Log.Lik. & 44.1 & 20.2 \\
F & -12.944 & -1.021 \\
& 7.478 & 52.983 \\
\hline$* \mathrm{p}<0.05, * * \mathrm{p}<0.01, * * * \mathrm{p}<0.001$
\end{tabular}

ARIMA Model

\begin{tabular}{lcc}
\hline & Lafayette & Ouachita \\
\hline Constant & 0.2 & 0.078 \\
& $(1.192)$ & $(0.509)$ \\
Consolidation & 0.161 & 0.037 \\
& $(1.035)$ & $(0.21)$ \\
\hline Model $(p, d, q)$ & $(0,1,2)$ & $(0,1,0)$ \\
AIC & -25.02 & -15.74 \\
BIC & -18.57 & -9.3 \\
ADF & -1.687 & -3.153 \\
ADF (p-value) & 0.696 & 0.123 \\
Ljung-Box (Q-Stat) & 1.75 & 6.23
\end{tabular}

Note: t-values shown in parentheses.

$* \mathrm{p}<0.05, * * \mathrm{p}<0.01, * * * \mathrm{p}<0.001$

Richmond \& Chatham Counties, Georgia (Consolidated 1996; VRA Preclearance) Linear Model

\begin{tabular}{lcc}
\hline & Richmond & Chatham \\
\hline (Intercept) & $0.630 * * *$ & $0.261^{*}$ \\
& $(0.074)$ & $(0.109)$ \\
Time & $0.019 * * *$ & $0.018^{* *}$ \\
& $(0.004)$ & $(0.006)$ \\
Consolidation & $5.802 * * *$ & -1.674 \\
& $(1.342)$ & $(1.960)$ \\
Time $\times$ Consolidation & $-0.168^{* * *}$ & 0.052 \\
& $(0.038)$ & $(0.056)$ \\
\hline Num.Obs. & 38 & 38 \\
R2 & 0.586 & 0.436 \\
R2 Adj. & 0.550 & 0.386 \\
AIC & -7.9 & 20.9 \\
BIC & 0.3 & 29.1 \\
Log.Lik. & 8.939 & -5.470 \\
$\mathrm{~F}$ & 16.051 & 8.750 \\
\hline$* \mathrm{p}<0.05, * * \mathrm{p}<0.01, * * * \mathrm{p}<0.001$
\end{tabular}

ARIMA Model

\begin{tabular}{lcc}
\hline & Richmond & Chatham \\
\hline Constant & 0.058 & -0.718 \\
& $(0.217)$ & $(-5.046)$ \\
Consolidation & 0.575 & 0.726 \\
& $(1.958)$ & $(5.305)$ \\
\hline Model $(p, d, q)$ & $(0,1,0)$ & $(3,1,0)$ \\
AIC & -11.03 & -8.61 \\
BIC & -6.2 & -0.56 \\
ADF & -1.984 & -2.939 \\
ADF (p-value) & 0.58 & 0.207 \\
Ljung-Box $(\mathrm{Q}-$ Stat $)$ & 1.75 & 6.64 \\
\hline Note: $\mathrm{t}-\mathrm{values}$ shown in parentheses. \\
$* \mathrm{p}<0.05, * * \mathrm{p}<0.01, * * * \mathrm{p}<0.001$
\end{tabular}


Wyandotte \& Geary Counties, Kansas (Consolidated 1998; No VRA Preclearance) Linear Model

\begin{tabular}{lcc}
\hline & Wyandotte & Geary \\
\hline (Intercept) & $0.443^{* * *}$ & 0.256 \\
& $(0.052)$ & $(0.161)$ \\
Time & $0.015^{* * *}$ & $0.021^{*}$ \\
& $(0.003)$ & $(0.008)$ \\
Consolidation & 1.714 & 4.258 \\
& $(1.674)$ & $(5.139)$ \\
Time $\times$ Consolidation & -0.053 & -0.134 \\
& $(0.047)$ & $(0.143)$ \\
\hline Num.Obs. & 38 & 38 \\
R2 & 0.490 & 0.182 \\
R2 Adj. & 0.445 & 0.109 \\
AIC & -32.2 & 53.1 \\
BIC & -24.0 & 61.3 \\
Log.Lik. & 21.077 & -21.536 \\
F & 10.884 & 2.517 \\
\hline$* \mathrm{p}<0.05, * * \mathrm{p}<0.01, * * * \mathrm{p}<0.001$
\end{tabular}

ARIMA Model

\begin{tabular}{lcc}
\hline & Wyandotte & Geary \\
\hline Constant & -0.436 & -0.178 \\
& $(-2.965)$ & $(-1.038)$ \\
Consolidation & -0.224 & -0.001 \\
& $(-2.072)$ & $(-0.004)$ \\
\hline Model $(p, d, q)$ & $(2,1,0)$ & $(0,1,0)$ \\
AIC & -47.33 & 9.18 \\
BIC & -40.89 & 14.02 \\
ADF & -1.986 & -1.484 \\
ADF (p-value) & 0.579 & 0.775 \\
Ljung-Box $(\mathrm{Q}-$ Stat $)$ & 2.88 & 2.43 \\
\hline Note: t-values shown in parentheses. \\
$*$ p $<0.05, * * \mathrm{p}<0.01, * * * \mathrm{p}<0.001$
\end{tabular}

Trousdale \& Giles Counties, Tennessee (Consolidated 2001; No VRA Preclearance) Linear Model

\begin{tabular}{lcc}
\hline & Trousdale & Giles \\
\hline (Intercept) & -0.091 & -0.016 \\
& $(0.068)$ & $(0.042)$ \\
Time & $0.030 * * *$ & $0.011^{* * *}$ \\
& $(0.003)$ & $(0.002)$ \\
Consolidation & 0.911 & 0.033 \\
& $(10.669)$ & $(6.592)$ \\
Time $\times$ Consolidation & -0.027 & -0.003 \\
& $(0.284)$ & $(0.176)$ \\
\hline Num.Obs. & 38 & 38 \\
R2 & 0.737 & 0.483 \\
R2 Adj. & 0.714 & 0.437 \\
AIC & -8.3 & -44.9 \\
BIC & -0.1 & -36.7 \\
Log.Lik. & 9.133 & 27.429 \\
F & 31.769 & 10.589 \\
\hline$* \mathrm{p}<0.05, * * \mathrm{p}<0.01, * * * \mathrm{p}<0.001$
\end{tabular}

ARIMA Model

\begin{tabular}{lcc}
\hline & Trousdale & Giles \\
\hline Constant & 0.417 & 0.101 \\
& $(2.692)$ & $(0.621)$ \\
Consolidation & -0.073 & 0.003 \\
& $(-0.703)$ & $(0.045)$ \\
\hline Model $(p, d, q)$ & $(0,1,1)$ & $(0,1,0)$ \\
AIC & -56.94 & -87.44 \\
BIC & -52.1 & -82.6 \\
ADF & -1.994 & -1.498 \\
ADF (p-value) & 0.576 & 0.77 \\
Ljung-Box (Q-Stat) & 3.31 & $12.7 *$ \\
\hline Note: t-values shown in parentheses. \\
$* \mathrm{p}<0.05, * * \mathrm{p}<0.01, * * * \mathrm{p}<0.001$
\end{tabular}


Haines \& Lake and Peninsula Counties, Alaska (Consolidated 2002; VRA Preclearance) Linear Model

\begin{tabular}{|c|c|c|c|c|c|}
\hline \multirow[b]{2}{*}{ (Intercept) } & \multirow{2}{*}{$\begin{array}{c}\text { Haines } \\
-0.437 \\
(0.306)\end{array}$} & Lake \& Peninsula & \multicolumn{3}{|c|}{ ARIMA Model } \\
\hline & & $\begin{array}{l}0.000 \mathrm{NA} \\
(0.000)\end{array}$ & & Haines & Lake \& Peninsula \\
\hline Time & $\begin{array}{l}0.327^{*} \\
(0.142)\end{array}$ & $\begin{array}{c}0.000 \mathrm{NA} \\
(0.000)\end{array}$ & Constant & $\begin{array}{l}\mathrm{n} / \mathrm{a} \\
\mathrm{n} / \mathrm{a}\end{array}$ & $\begin{array}{l}\mathrm{n} / \mathrm{a} \\
\mathrm{n} / \mathrm{a}\end{array}$ \\
\hline Consolidation & $\begin{array}{l}1.171^{* * * *} \\
(0.316)\end{array}$ & $\begin{array}{l}0.000 \mathrm{NA} \\
(0.000)\end{array}$ & Consolidation & $\begin{array}{l}\mathrm{n} / \mathrm{a} \\
\mathrm{n} / \mathrm{a}\end{array}$ & $\begin{array}{l}\mathrm{n} / \mathrm{a} \\
\mathrm{n} / \mathrm{a}\end{array}$ \\
\hline Time $\times$ Consolidation & $\begin{array}{l}-0.324^{*} \\
(0.142)\end{array}$ & $\begin{array}{c}\text { NA } \\
(0.000)\end{array}$ & $\begin{array}{l}\text { Model }(p, d, q) \\
\text { AIC }\end{array}$ & $\begin{array}{c}(0,0,0) \\
n / a\end{array}$ & $\begin{array}{c}(0,0,0) \\
\mathrm{n} / \mathrm{a}\end{array}$ \\
\hline Num.Obs. & 38 & 38 & BIC & $\mathrm{n} / \mathrm{a}$ & $\mathrm{n} / \mathrm{a}$ \\
\hline $\mathrm{R} 2$ & 0.464 & & $\mathrm{ADF}$ & $\mathrm{n} / \mathrm{a}$ & $\mathrm{n} / \mathrm{a}$ \\
\hline R2 Adj. & 0.417 & & ADF (p-value) & $\mathrm{n} / \mathrm{a}$ & $\mathrm{n} / \mathrm{a}$ \\
\hline AIC & -8.6 & & Ljung-Box (Q-Stat) & 0 & 0 \\
\hline $\begin{array}{l}\text { BIC } \\
\text { Log.Lik. }\end{array}$ & $\begin{array}{l}-0.4 \\
9.285 \\
9815\end{array}$ & & $\begin{array}{l}\text { Note: t-values shov } \\
{ }^{*} \mathrm{p}<0.05,{ }^{* *} \mathrm{p}<\end{array}$ & $\begin{array}{l}1 \text { in parent } \\
.01, * * * \mathrm{p}\end{array}$ & $\begin{array}{l}\text { eses. } \\
0.001\end{array}$ \\
\hline
\end{tabular}

